\title{
Avaliação e perspectivas da abordagem à conservação do patrimônio organístico no Brasil
}

\begin{abstract}
Elisa Freixo ${ }^{2}$
Andrea Cavicchioli ${ }^{3}$

RESUMO: Órgãos de tubos são construídos no Brasil, ou importados do exterior, desde as primeiras décadas do período colonial. Estes instrumentos, apesar de constituírem um conjunto relativamente exíguo, representam um testemunho histórico e musical de valor inestimável. No entanto, de um modo geral, encontram-se em condições precárias de funcionamento e, em parte, mais ou menos descaracterizados profundamente, quanto à sua estrutura e configuração original, às vezes em estado de abandono e, por incrível que pareça, ainda sujeitos ao risco de intervenções arbitrárias e desprovidas de bases técnicas e de preocupação histórica e musicológica. Neste artigo, busca-se percorrer o caminho que levou à atual situação e discutem-se os princípios e os critérios de processos de recuperação, manutenção e conservação preventiva desse patrimônio, partindo dos pressupostos do respeito à sua originalidade e do direito a restauros segundo os rigorosos cânones já definidos para objetos com plena condição de bem cultural, cujo reconhecimento para os órgãos de qualquer época deve ser urgentemente garantido.

PALAVRAS-CHAVE: Órgãos de tubos. Patrimônio histórico-cultural. Restauro. Conservação preventiva.

ABSTRACT: Pipe organs have been built in Brazil or imported from elsewhere since the very first decades of the colonial period. Albeit relatively small in number, such instruments have inestimable historical and musical value. Notwithstanding, they are generally in very poor working condition and some have lost much of their original structure and configuration; they are often found in a state of abandonment and, incredible as it may seem, still under the threat of arbitrary interventions performed with no technical expertise or any concern for their historical and musicological significance. This article is an effort to understand how this state of affairs came to be, and discusses principles and criteria for the restoration, maintenance and preventive conservation of this legacy, based on assumptions regarding its original conditions and entitlement to restoration in accordance with the stringent standards already set for artifacts
\end{abstract}

\author{
1. Agradecemos à Fapesp \\ (projeto N. 06/61437-3) e à \\ Comissão Européia (projeto \\ N. 022695, 6th Framework \\ Programme) pelo fomento à \\ pesquisa. \\ 2. Organista. E-mail: <efrei- \\ xo@terra.com.br> \\ 3. Docente da Escola de \\ Artes, Ciências e Humanida- \\ des da Universidade de São \\ Paulo (EACH/USP). E-mail: \\ <andrecav@usp.br>.
}


4. Ver Dorotéa Kerr (1985).

5. Ver Dorotéa Kerr (2001).

6. Ver Anne Schneider (1994).

7. Ver Calimério Soares (1989; 1991).

8. Ver Guy Bovet e Elisa Freixo (1987)

9. Segundo Dufourcq (1935), apud Marco Aurélio Brescia (2008), são considerados "órgãos clássicos" aqueles construídos entre o século $\mathrm{XIV}$ e as primeiras décadas do século XIX. É uma distin ção bem estabelecida no meio organístico, englobando instrumentos que, ao longo desse período, mantiveram características semelhantes, por exemplo, tração mecânica e possibilidade da escuta polifônica

10. De dois desses instrumen tos os autores têm notícia somente de sua provável existência, sem ter tido condições de acessá-los e examiná-los.

11. Ver Marco Aurélio Brescia (2008)

12. Basta pensar que, dos 65 instrumentos catalogados por Anne Schneider (1994), somente 22 constavam na relação de Dorotéa Kerr (1985). É claro que as catalogações realizadas até hoje estão sempre sujeitas a contínuas atualizações.

13. Ver Gustavo Delgado Parra e Ofélia Gómez Castellanos (1999). that enjoy the full status of cultural assets, which should also be urgently granted to pipe organs of any time and age.

KEYWORDS: Pipe organs. Historical and cultural heritage. Restoration. Preventive conservation.

Introdução

patrimônio organístico no Brasil, hoje, é constituído provavelmente por algumas centenas de exemplares. Tal informação se baseia tanto na experiência pessoal dos autores como nos dados disponíveis em alguns inventários realizados nos últimos trinta anos. Entre eles, destacam-se: I) o catálogo apresentado em anexo à dissertação de mestrado de Dorotéa Kerr ${ }^{4}$, no qual são fichados 218 órgãos de todo o Brasil las condições técnicas e as histórias dos 54 da cidade de São Paulo são detalhadamente descritas num livro da mesma autora ${ }^{5}$; II o levantamento de Anne Schneider sobre 65 instrumentos encontrados no estado do Rio Grande do Sulb; III) trabalhos de Calimério Soares, focando os 14 órgãos de manufatura Cavaillé-Coll7; e IV) o estudo de Bovet e Freixo decorrente de visitas a órgãos barrocos nos estados de São Paulo, Pernambuco, Bahia, Minas Gerais e Pará ${ }^{8}$.

Segundo a recente pesquisa de Brescia, 17 órgãos (ou caixas de órgão) em estilo clássico9', sobrevivem nos estados de Minas Gerais, Bahia, São Paulo, Rio de Janeiro e Pará ${ }^{10}$, entre eles o Arp Schnitger, da Catedral da Sé, em Mariana (MG), e o Fernandes Coutinho, da Matriz de Santo Antônio, em Tiradentes (MG), que hoje se encontram em excelentes condições físicas e em funcionamento, sendo tocados em programas regulares de concertos e em cerimônias religiosas. Dos instrumentos das igrejas de Nossa Senhora do Carmo, em Belém (PA), de Nossa Senhora do Carmo, no Rio de Janeiro (RJ), e de Nossa Senhora do Bonsucesso, em Caeté (MG), bem como do Mosteiro de São Bento, no Rio de Janeiro, e da Capela da Fazenda do Rio São João, em Bom Jesus do Amparo (MG), resta somente a caixa. Já três órgãos em Salvador (BA), dois em São Paulo (SP), e três outros em Minas Gerais, respectivamente, em Diamantina, em Córregos e em São João del Rei, embora atualmente num estado que impede sua utilização, contêm elementos suficientes para um restauro que os reconduza a uma estrutura próxima à original ${ }^{11}$.

Os números aqui citados, por incertas que as estimativas ainda possam ser, em função de diversos fatores - e não por último a extensão do território -, servem para dar uma idéia do tamanho do corpus de órgãos no país ${ }^{12}$. São cifras que podem parecer desprezíveis, perante a quantidade de instrumentos históricos na Europa (mais de 10 mil) e até mesmo no resto da América Latina. No México, por exemplo, só na região de Oaxaca foram identificados 68 órgãos construídos entre 1686 e 1900, segundo os dados do Instituto de Órgãos Históricos de $\mathrm{O} \mathrm{xaca}^{13}$, um número já muito maior do que a quantidade de instrumentos do mesmo período histórico encontrados em todo o Brasil. Este, de qualquer forma, é o montante de instrumentos que temos no Brasil e esta suposta exiguidade, 
conforme se queira ver, é também a nossa única riqueza no âmbito organístico e, antes de mais nada, é a partir desses números que se deve avaliar a importância e a urgência de uma discussão séria sobre as modalidades do resgate dos próprios instrumentos, em função da revitalização da cultura organística no Brasil.

O declínio do órgão no país já foi discutido em outros trabalhos ${ }^{14}$. É incontestável que este instrumento sempre foi, aqui e no resto do mundo, associado a celebrações eclesiásticas, católicas e protestantes, e que boa parte da música escrita para órgão seja música sacra e, portanto, haja uma relação estreita entre o desinteresse pela música organística que hoje vivenciamos e o processo de afrouxamento do sentimento religioso que a sociedade sofreu no século XX, as mudanças na liturgia católica introduzidas pelo Concílio Vaticano II, e o surgimento de novas religiões que atraem cada vez mais fiéis e propõem formas distintas de adoração. No entanto, não devemos ignorar a possibilidade de que o declínio do interesse pela música para órgão, especificamente no Brasil, possa estar relacionado ao próprio processo de degradação física do patrimônio organístico. A situação de abandono e destruição descrita para os órgãos barrocos, com as importantes exceções já mencionadas, estende-se tanto aos órgãos do período romântico como aos de feitura muito mais recente. Por exemplo, o Balbiani Vegessi-Bossi, da Catedral da Sé de São Paulo (1954), vem acumulando problemas desde sua instalação (ver o relato de Kerr ${ }^{15}$ ), praticamente nunca resolvidos no decorrer das várias reformas e agravados pelo fato de ser a resposta acústica na igreja desastrosa, em função da escolha inadequada do local de instalação. Também o Tamburini, do Teatro Municipal de São Paulo (1969), desde o início sofreu a corrosão dos tubos de lingueta, que se especula ser devida ao fato de o ar de alimentação ser captado diretamente da atmosfera externa do teatro, sabidamente poluída - e, embora não se tenha conhecimento de estudos que corroborem a hipótese, não se exclui que o problema possa estar relacionado simplesmente a uma má combinação de ligas metálicas e madeira.

De qualquer forma, há aqui casos de grandes instrumentos importados e custosos, cuja implantação não redundou num impacto do mesmo porte na vida musical da cidade, devido a vários problemas estruturais que, em tempos mais ou menos curtos, levam à sua inutilização e que, via de regra, raramente são abordados de forma adequada, apesar dos conspícuos investimentos para a sua manutenção e recuperação ao longo dos anos. E se isso aconteceu foi inclusive (ou especialmente) porque, parece-nos, lidou-se com a manutenção de máquinas complexas e sensíveis de uma forma que, às vezes, ficamos tentados a definir como amadorística, mas certamente sem o necessário suporte de conhecimento técnico, de escrúpulo histórico, de visão musical e artística, que deveriam vir acompanhando uma escola e a uma tradição organeira consolidada.

Há uma lacuna, esta no Brasil, indicada pela presença atual de poucos instrumentos e majoritariamente de além-mar. É sabido que foram trazidos órgãos da metrópole já desde as primeiras décadas da colonização e durante os séculos XVII e XVIII, quando ainda do monopólio comercial da coroa portuguesa. Já nos séculos XIX e XX, houve uma contribuição mais marcante de França, Inglaterra, Alemanha e Itália, sendo que, no mínimo, três fatores foram determinantes neste
14. Ver Dorotéa Kerr (1985); Calimério Soares (2001); Júlio C. Amstalden (2001).

15. Ver Dorotéa Kerr (2001). 
16. Ver Marco Aurélio Brescia (2008); Handel C. P. da Silva (2008).

17. Na infeliz circunstância de uma enorme falta de instrumentos que testemunhem concretamente tal atividade, Marco Aurélio Brescia nos esclarece que temos de recorrer a quatro tipos de recursos para resgatar as informações necessárias: 1) Registros escritos de construção ou importação; 2) registros que fazem referência à contratação e à atividade de organistas; 3) relatos de viajantes, diários, crônicas da época; 4) registros iconográficos.

18. Kastner apud Marco Aurélio Brescia (2008).

19. Ver Marco Aurélio Brescia, (2008).

20. Ibidem.

21. Ver Francisco Curt Lange (1979; 1981).

22. Ver Jaime C. Diniz (1986). processo a partir da segunda metade de 1800: a disseminação do cristianismo reformado; a euforia despertada pela introdução, na França, do órgão romântico; e os vínculos criados com determinados países pela chegada dos imigrantes.

Dito isso, tem-se de reconhecer, no entanto, que, durante pelo menos dois momentos na história do Brasil, verificaram-se condições que levaram, se não exatamente à instalação de ateliês de construção duradouros e de empreendimentos sólidos, pelo menos à existência de organeiros isoladamente bastante ativos. Em ambos os casos, isso se deu, inclusive, como resposta às dificuldades de importação de instrumentos desta complexidade e porte, ato que sempre envolveu (e envolve, todavia) esforços consideráveis financeiros e de transporte, não sem consequências negativas no resultado final (sirva o órgão da Sé de São Paulo como exemplo emblemático).

A primeira destas duas fases de produção autóctone ocorreu durante o período colonial, ao que se presume ${ }^{16}$, com a construção de pequenos positivos, dos quais não resta quase nenhum ${ }^{17}$. Como na Europa, no século XVIII, aconteceu o desaparecimento ou o remanejamento dos instrumentos mais antigos ${ }^{18}, \mathrm{e}, \operatorname{assim}$, a quase totalidade dos instrumentos presentes no Brasil nos séculos XVII e XVIII foi destruída ou depredada em épocas posteriores. Como sempre acontece nesses casos, nos centros menores ou que ao longo dos anos perderam importância e poder econômico para adquirir novos órgãos (Mariana, Tiradentes, Diamantina, Córregos, Embu, por exemplo), eles foram mais bem resguardados. Três deles, praticamente com certeza, foram construídos in situ: são os órgãos das igrejas da Ordem Terceira de Nossa Senhora do Carmo, de Diamantina (Pe. Manuel de Almeida e Silva, 1782-1787)19, de Nossa Senhora Aparecida, de Córregos (talvez Francisco Leonardo Ramos, primeira metade do século XIX ${ }^{20}$ e da Capela de Nossa Senhora do Rosário, de Embu das Artes (não há notícias sobre a origem do instrumento, mas suas características indicam uma provável manufatura local).

Além do Pe. Manuel de Almeida e Silva e de Francisco Leonardo Ramos, dos quais não temos praticamente informações biográficas, vários construtores de órgãos são citados nos livros de Curt lange ${ }^{21}$ e de Jaime Diniz ${ }^{22}$, destacando-se Agostinho Rodriguez Leite (1722-1786), ativo em Pernambuco, mas autor também de instrumentos encontrados no Rio de Janeiro, e Athanazio Fernandez da Silva (1767-2). E ainda: Frei Mathias e Pe. João Fagundes (ainda no séc XVII.); Antonio Paulo da Silva, Antonio Francisco Lisboa, Salvador Francisco Leite (filho de Agostinho), Manoel Ignácio Valcacer e João Xavier Traer (no Pará).

É difícil avaliar a habilidade profissional dessas pessoas, a não ser nos raros casos em que suas obras tenham sobrevivido até nós. Diniz, a respeito do Pe. Manuel de Almeida e Silva, escreve:

Não conhecemos o menor antecedente sobre a aprendizagem do padre no campo da organeria, se adquirida em Portugal ou se improvisada no Tejuco à base de textos e planos recebidos de Lisboa. [...]. É fora de dúvida que o órgão do Carmo representou o maior esforço do Padre Almeida e Silva, se considerarmos os respectivos custos de cada um de seus empreendimentos [300 e 1100 oitavas de ouro, respectivamente, fora o custo do órgão de Santo Antônio e do Carmo]. Para o Arraial do Tejuco foi um esforço extraordinário e o lapso que se acha entre a assinatura do contrato e a conclusão do órgão comprova que o Padre 
Almeida e Silva deve ter lutado com sérias dificuldades para entregá-lo perfeito e acabado. Parece que não soube solucionar um problema surgido nos foles, os quais tiveram que ser constantemente renovados ou reparados ao longo de vários decênios. ${ }^{23}$

Já Brescia ressalta a riqueza dos registros desse mesmo órgão e do de Córregos, remetendo implicitamente, com isso, à função do instrumento, preservado na sua forma original, para o resgate de informações valiosas sobre a prática musical da época: "une telle diversité de registres ne serait pas justifiée si les instruments se destinassent uniquement à l'accompagnement des ensembles musicaux" 24 .

Uma segunda fase significativa de produção local deu-se no século XX. Já foram resgatadas as trajetórias de vários organeiros que implantaram suas atividades no Rio de Janeiro ${ }^{25}$ e, sobretudo, em São Paulo entre os anos de 1920 e 197026. Tratava-se de imigrantes alemães e italianos que tinham alguma experiência, adquirida em grandes firmas de além-mar, mas não sempre. Henrique Lins (1906-1985)27, relata Kerr: "sabendo marcenaria, foi chamado a ajudar o padre da igreja local [Seminário Menor de Sorocaba] na montagem de um órgão Stehle que acabara de chegar da Alemanha. 'Foi aí que eu mexi num órgão pela primeira vez"'28

João Edmundo Bohn (1899-1968), autor de um grande número de instrumentos na região sul do Brasil, "lidava com relógios, mas começou a fazer harmônios e deu certo, então com 30 anos passou a construir órgãos de tubos" 29 .

Já Gotholdo Budig (falecido por volta de 1926), Carlos Möhrle (falecido em 1973) e Guilherme Berner (1907-1951) transitaram em escolas alemãs de organaria: a Saver, a Walker e a Steinmeyer, respectivamente. Giuseppe Petillo (falecido em 1945) era oriundo de uma família napolitana de organeiros, mas, uma vez, Ângelo Camin disse dele: "era um ótimo sujeito. Tinha muito boas intenções, mas nunca deixou um órgão terminado com perfeição" 30 .

É extremamente instrutivo o que a mesma Kerr diz a seu respeito: "Não há notícias de que tenha feito no Brasil uma extensão da fábrica de seus parentes. [...] Tinha uma oficina com poucos empregados. [...] Dedicava-se principalmente a utilizar partes de outros órgãos já existentes por ele desmontados e comprados" 31 .

Esta característica de usar muitas vezes peças de instrumentos anteriores e importar outras de ateliês especializados estrangeiros deve ter sido comum a, além de Petillo, todos profissionais dessa época. Veja-se Berner em seu folder de divulgação: "Essa nova indústria nacional teve o seu início marcado pelas circumstâncias naturaes, em que o Brasil se encontrava nestes últimos annos: [...] 3. Necessidade de substituir os órgãos antigos inteiramente ou em parte destruídos pela acção do tempo, e cujo concerto [sic] se demonstrava impossível" 32 .

Trata-se de uma atitude que deve ser entendida à luz da formação cultural limitada não só dessas personagens, mas também do contexto histórico e, afinal, da necessidade dos donos e usuários finais dos instrumentos (também sem acesso a outras alternativas) às quais eles atendiam, mas cujo prejuízo sobre
23. Idem, p. 126.

24. Cf. Marco Aurélio Brescia (2008, p. 91).

25. Ver Gisele S. Batista (2009).

26. Ver Dorotéa Kerr (2001).

27. Os dados biográficos usados nesta seção foram extraídos de Dorotéa Kerr (2001) e Anne Schneider (1994).

28. Cf. Dorotéa Kerr (2001, p. 33).

29. Cf. Anne Schneider, (1994, p. 35).

30. Camin (1985), apud Dorotéa Kerr (2001, p.250).

31. Cf. Dorotéa Kerr (2001, p. 36).

32. Berner (1933) apud Dorotéa Kerr (2001, p. 35). 
33. Construtor de órgãos de tubos francês (1811-1899) de excepcional importância por ter concebido o órgão romântico e ter construído centenas de instrumentos de grande relevância espalhados no mundo inteiro.

34. Cf. Dorotéa Kerr (2001, p. 227).

35. Cf. Calimério Soares (1989, p. 74). Por outro lado, graças ao enorme conhecimento que se tem, na Europa, da manufatura Cavaillé-Coll, existe a possibilidade de um restauro que o reaproxime ao instrumento original.

36. Cf. Gisele S. Batista e Dorotéa M. Kerr (2009, p. 2) o patrimônio histórico organístico brasileiro é provavelmente incalculável. Pelo exame dos catálogos bem como pela experiência direta de organistas junto aos instrumentos de São Paulo, pode-se dizer que hoje é raro encontrar na cidade um único instrumento com mais de 70 anos de idade que não tenha recebido alguma intervenção, com trocas de suas partes com peças de outros órgãos, ou que, de alguma maneira, não tenha tido suas características originais fortemente alteradas. Sirvam de exemplo os dois órgãos Aristide Cavaillé-Coll|33 (Igreja São José, do Ipiranga, 1863; e Igreja Bom Jesus, do Brás, 1875): o primeiro foi alterado por G. Budig e, sucessivamente, por Carlos Moehrle (1955) e José Carlos Rigatto (1970) numa "adaptação que descaracterizava completamente o instrumento"34. Do segundo, Calimério Soares afirma que:

O estado geral deste pequeno, porém retalhado instrumento, é bastante ruim. Não obstante a reforma feita em 1984 por Lucas Bertucca Filho, várias conexões encontram-se desativadas, havendo muitos tubos emudecidos e mesmo timbrando mal e a desafinação é total. [...] Resgatá-lo aos moldes originais seria impossível, pois muito poucas peças originais existem ${ }^{35}$.

Os organeiros italianos e alemães mencionados, atuantes em São Paulo e no Rio de Janeiro, mais cedo ou mais tarde fecharam suas fábricas, embora tenham contribuído para formar uma segunda geração de profissionais, dos quais alguns se dedicaram a construir seus próprios órgãos (Salvatore Lanzilotta, Nicolau Larusso), enquanto outros voltaram-se para a atividade de manutenção e reforma: José Carlos Rigatto e os filhos Marcio e Daniel, Ricardo Clerice e José Darulhes Neto.

É bastante assustador verificar, numa época em que já se considera a preservação do patrimônio cultural como uma conquista firme e consolidada, que a atenção com a preservação do órgão e a preocupação com a sua integridade para fins históricos e musicais sejam no Brasil ainda tão incipientes, embora esporadicamente se encontre a manifestação de uma preocupação com "a falta de manutenção, demolições e transformações arbitrárias e irreversíveis dos instrumentos" 36 .

A esse propósito, cabe citar trechos de algumas reportagens sobre intervenções em órgãos importantes, evidenciando a extensão do problema, embora sejam veiculadas em tons entusiásticos, devido à reativação dos instrumentos.

O órgão Walcker da Igreja Luterana "Martin Luther", a Rua Carlos Sampaio no 251 - Centro, Rio de Janeiro (RJ) foi solenemente reinaugurado na manhã do domingo 12 de dezembro de 2004. [...] ○ fole, que estava irrecuperável, teve de ser substituído por outro totalmente novo, "fabricado com os melhores materiais, de forma profissional e exemplar. $\bigcirc$ mesmo julgamento também para os dois foles de compensação, igualmente novos", segundo o parecer do Protocolo de Homologação. O console do órgão, antes integrado ao corpo do instrumento na tribuna atrás do altar, foi desmembrado e transferido para baixo, para a nave da igreja ao lado do altar, com vistas a viabilizar maior interatividade entre organista e oficiante nos cultos, melhor integração do órgão com coro e outros instrumentos, etc. "Indo além das cláusulas contratuais, os restauradores trocaram todas as plaquetas dos registros por no- 
vas; todos os revestimentos de celulóide das teclas foram substituídos, três pedaletes foram instalados como registros auxiliares para o organista (combinações livres 1 e 2 e tutti); as teclas da pedaleira foram renovadas com madeiras melhores, de cores diferentes entre as teclas superiores e inferiores"; um moderno sistema computadorizado de controle do pedal expressivo foi importado dos Estados Unidos e instalado. Os someiros foram completamente restaurados, todos os eletroímãs trocados por peças importadas da ltália, todos os folezinhos igualmente trocados. Num trabalho meticuloso e delicado (soldas homogêneas nos tubos metálicos, calafetagem de fissuras nos de madeira), todos os tubos foram restaurados e colocados em situação perfeita ${ }^{37}$.

No relato, vê-se como a ênfase do restauro foi totalmente na troca, na substituição e na modernização, num trabalho apresentado como "meticuloso e delicado", mas na verdade caracterizado por uma falta irresponsável de escrúpulo histórico e de respeito às peculiaridades próprias de um instrumento de mais de 80 anos.

Também, no relato sobre a restauração do órgão da igreja de N. S. de Fátima, São Paulo, lê-se da restauração e da substituição de alguns (quantos?) tubos e da automatização de um instrumento nascido para ser pneumático:

Fabricado na Alemanha com o sistema de tração pneumática pela fabrica Gebrüder Späeth, em 1908, e instalado no mosteiro São Bento em São Paulo. Em 1956 foi transferido para o Santuário Nossa Senhora do Rosário de Fátima, restaurado e ampliado com uma nova console Walker, pelo organeiro Reiner Michels.

Em 2006, depois de 10 anos sem condições de uso, foi contratada a firma Família Artesã Rigatto e Filhos para os trabalhos. [...]

O móvel interno, os foles e as janelas de expressão que se encontravam atacados pelo cupim foram totalmente refeitos.

Diversos someiros novos, algumas tampas de someiros e suportes de tubos foram refeitas com madeira de lei, bem como os tubos restaurados e diversos fabricados. As válvulas dos tubos e os solenóides foram substituídos.

A console foi refeita: painel com tabletes reversíveis, botões para a chamada das combinações ajustáveis (memória com combinações) adaptação de um sistema digital moderno, que utiliza uma central no interior da console e outra no órgão, obtendo a vantagem de ter mais de 2.500 combinações ajustáveis, 12 transpositores, conexão para computador onde se pode programar todo o sistema, escrever partituras, gravar e reproduzir da memória interna através de porta USB ${ }^{38}$.

Não temos conhecimento direto da extensão das alterações nem da existência de documentos onde possam ser encontrados os detalhes dessas intervenções (uma lacuna, aliás, bastante comum nos trabalhos em órgãos, executados no Brasil) e tampouco se as firmas alemãs Walker e Späeth, ainda em atividade, foram consultadas previamente, como se esperaria.

Daniel e Márcio Rigatto moram na Pompéia, são organeiros e explicam todos os detalhes deste trabalho:

"Um organeiro constrói e restaura órgãos. Existem organeiros especializados só em restauração e outros só na construção. O organista é o que toca".
37. O relato se refere ao órgão da Comunidade Luterana Martin Lutero, do Rio de Janeiro fabricado por E. F. Walker\&Co, Ludwigsburg, 1928 , segundo a ficha apresentada no mesmo relato. Disponível em: <http:// www.luteranos.com.br/attachments/ centrorio/Artigo_ sobre_orgao_Walcker_2198. pdf>. Acesso 20 nov. 2009.

38. Relato sobre a restauração do órgão da igreja de N.S. Fátima, São Paulo. Disponível em: <http://www.santuariofatima.com.br/exibe_noticia. php? not $=125>$. Acesso 20 nov. 2009. 
39. Disponível em: <http:// s p t v.g 1 o bo . c o m / Sptv/0, 19125, LPO06150$-20080712-325480,00 . \mathrm{html}$. Acesso 20 nov. 2009.

40. Disponível em: http:// s p t v. g 1 o b o . c o m / Sptv/0,19125,LPO06146-20070412-275830,00.html . Acesso em 20 nov. 2009.
"Estamos finalizando a harmonização do órgão de Nossa Senhora de Fátima, no Sumaré. O console é onde o organista executa a música. Depois, você tem o sistema de tração, que seria do teclado até o someiro, que é uma peça interna. Ele é eletrônico, tem um computador. Deste computador, o someiro faz a passagem, manda um sinal para os solenóides. Lá dentro, continua ainda o material de 1908, que é um material todo pneumático".

"Ele veio da Alemanha, foi inaugurado em 1908 no Mosteiro de São Bento de São Paulo. Em 1956, ele foi montado na Nossa Senhora de Fátima. Já havia doze anos que ele estava parado, mas hoje ele está completando 100 anos; é o centenário desse belíssimo instrumento que, por pouco, não perdemos".

"Quando nós chegamos aqui, o instrumento estava totalmente abandonado, com cupim. Algumas partes foram restauradas, como os someiros, onde descansam os tubos. Os solenóides são novos, foram todos substituídos. Há também peças novas, que são embuia, madeira brasileira. Por sorte, conseguirmos manter a fachada original, porque é de carvalho europeu e é difícil o cupim pegar este tipo de madeira".

"Demorou dois anos e três meses o processo completo de restauro. Nós estamos finalizando e daqui algumas semanas ele já estará entregue. Na alma do órgão, são 2,5 mil tubos divididos em quatro divisões: tem o grande órgão, o expressivo terceiro manual, o positivo primeiro teclado e o pedal atrás, que são os tubos grandes".

"A harmonização dos tubos é feita de um por um. Eu fico no console e ele aqui dentro. Então, eu sou obrigado a escutar o som lá e depois eu me comunico com ele", explica Márcio.

"O órgão é uma paixão desde criança. $O$ meu pai também era organista. Então, nas missas eu acompanhava, na liturgia, nos concertos de órgãos. E peguei gosto pelos trabalhos, principalmente a parte de tubos, projetos de tubos, fabricação, restauração e parte sonora - a harmonização, a afinação. E um belo dia eu senti vontade de conhecer todo o processo da construção de um instrumento. Foi quando eu tive essa oportunidade na Fratelli Rufatti, uma fábrica em Padova, no nordeste da ltália, e ali eu passei por todas as fases, seja na construção, seja na restauração"39.

Aqui, queremos questionar a ausência de pesquisas prévias sobre a adequação da embuia: hoje, os especialistas não podem desconhecer que uma escolha inadequada da madeira pode, futuramente, causar danos irreparáveis às partes metálicas, especialmente aos tubos, resultando num problema conhecido no meio como "câncer do metal" (na verdade, um processo de corrosão iniciado por ácidos orgânicos voláteis liberados pela madeira). Ainda na mesma entrevista se aborda a questão do restauro do órgão da igreja de S. Cecília, em São Paulo:

O velho órgão alemão da igreja de Santa Cecília na região central da cidade sente os efeitos do tempo. "Foi praticamente o primeiro órgão de concertos que São Paulo teve." [...]. Para o instrumento ficar como antes ou ainda melhor é necessária uma restauração completa [...] "Ele vai ser sem dúvida o melhor instrumento pra concertos da América Latina ele vai ter uma memória eletrônica que ajuda o organista a fazer as combinações", garante Márcio Rigatto, restaurador ${ }^{40}$.

Encerramos esta resenha com entrevistas realizadas com José Carlos Rigatto, o filho Márcio e Joaquim Marçal Batista, igualmente esclarecedoras enquanto mostram posturas diametralmente opostas com relação ao restauro de um dos órgãos de manufatura do organeiro Guilherme Berner, objeto da dissertação 
de mestrado de onde foram extraídas ${ }^{41}$. De um lado temos José Carlos Rigatto ${ }^{42}$, que na entrevista dada a Batista mostra um método de trabalho muito centrado em substituições e modernizações técnicas:

Ah, nós fizemos muita coisa lá [órgão Berner na igreja de S. Cruz dos Militares]. Os eletro-imãs foram todos trocados. Foram restaurados todos os tubos, alguns refeitos. Diversos someiros foram refeitos também. Os acoplamentos são totalmente novos, com tração eletro-eletrônica. Foram acrescentados mais acoplamentos, inclusive union off. A consola foi totalmente refeita, aproveitando-se apenas o móvel, que é de madeira excelente. $O$ teclado e pedaleira foram restaurados: nos teclados foram colocados contatos ópticos e na pedaleira contatos de sensor magnético. Na janela de expressão também foram feitos novos aparelhos com um motor com comando eletrônico, possibilitando uma maior graduação e precisão na expressão $0^{43}$.

filho Márcio, sobre o mesmo restauro, acrescenta:

Alguns tubos foram restaurados; vários foram modificados, re-escalados, ou seja, o diâmetro foi modificado. Posso citar um exemplo de alguns registros que eu lembro: um que eu lembro bem era o 2'. O 2' do Grande-órgão era um Piccolo, uma flauta. Então ele foi re-escalado pra ter o resultado sonoro de uma Oitava 2', um registro de Principal 2' para completar o pleno. Outro também foi o Trompete, que antes parecia mais uma marreca cantando; estava fora de medida. Foram feitas algumas modificações nas pontas e as palhetas são novas ${ }^{44}$.

Trata-se de alterações muito profundas na composição sonora do instrumento, que mudam completamente sua concepção original. Já Marçal reconhece: "Eu concorri lá pra fazer a restauração, mas eu estava querendo manter a originalidade do órgão. No entanto, quando falaram que eles queriam mudar, eu caí fora, pra mim não dá. $\bigcirc$ interessante é você manter a originalidade do órgão e eu bato nessa tecla"45.

Acrescentamos que substituição do sistema pneumático por sistema elétrico está registrada no órgão Walker, da igreja da Imaculada Conceição (São Paulo), no órgão Bohn, da Catedral de São Francisco das Chagas (Taubaté/SP), e em muitos outros instrumentos restaurados em todo o país ${ }^{46}$.

Hoje podemos pensar no resgate da música organística promovendo a recuperação dos instrumentos, embora evidentemente para isso sejam necessárias não só uma real vontade do Estado e dos atores culturais para que aconteça mas que haja, também, a implementação de ações adequadas de política cultural. Para esta finalidade, não há dúvida de que a ampliação de cursos superiores, inclusive de pós-graduação e de pesquisas voltadas para a identificação e o estudo do patrimônio organístico, também tem uma função importante ${ }^{47}$. Mas, mais do qualquer outra idéia, o que nos interessa realçar é a firme convicção de que recuperar um órgão deve sempre significar muito mais do que colocar um instrumento para produzir um som a qualquer custo: é o resgate da possibilidade de uma experiência musical associada a um instrumento com características praticamente únicas. Um órgão barroco para ouvir música barroca, um órgão alemão para entender mais sobre a musicalidade daquela cultura, e um órgão
41. Ver Gisele S. Batista (2008).

42. José Carlos Rigatto, na mesma entrevista, mostra ter começado como organeiro também de uma forma quase casual e sem uma formação musical prévia: "Eu entrei na organaria adquirindo a fábrica do Carlos Möhrle. Então fiquei com os empregados alemães que ele tinha". Ver Gisele S. Batista (2009).

43. Ibidem.

44. Ibidem.

45. Ibidem.

46. Quanto à cidade de São Paulo, ver Dorotéa Kerr (2001).

47. Ver Dorotéa Kerr e Any Raquel Carvalho (2005). 
48. Cf. Kerala J. Snyder (2002b, p. 21).

49. Kastner apud Marco Aurélio Brescia (2008 p. 62).

50. Ver Elisa Freixo (2000; 2002).

51. Ver capa em Kerala J. Snyder (2002a). construído no Brasil para ouvir uma "voz" brasileira. Uma preocupação que precisa ser ainda mais profunda por envolver um instrumento cujo repertório cobre um tempo tão longo, durante o qual o gosto, a percepção musical e até a afinação sofreram incríveis mudanças (além de tudo, distintas nos diversos paises) e acompanharam a sua estrutura e as suas especificações. Isso implica, também, em não acreditar que um órgão possa suprir satisfatoriamente todas as possibilidades de repertório, somente por ter um grande porte:

To the aesthetic of our own time belongs the recognition that no one organ, no matter how large or eclectic, is adequate to the task of performing every part of the vast repertory for the instrument which extends over seven centuries. We know that the music of Cesar Franck is not at home in a neo-baroque organ, and we have learned that pieces from the sixteenth and seventeenth centuries that appear uninteresting on a modern instrument spring to life when played on a mechanical-action organ with a short octave and the proper stops, tuned in meantone ${ }^{48}$.

\section{Ou ainda:}

Chaque pays ou région de notre continent possède son propre e pérenne ideal sonore, as manière particulière de concevoir en matière de facture d'orgues, de sorte que toute et n'importe quelle contribuition technique ou esthétique foraine seulement peut réussir à établir sés racines dans um terrain d'autrui, sous la condition de s'adapter au goût commun en vigeur dans son nouveau milieu 49 .

A este respeito, se não reconhecêssemos o caráter norte-alemão conferido pela personalidade de Arp Schnitger ao órgão de Mariana (com todo o esforço que foi feito no começo do século XVIII, quando da vinda para Portugal, para se aproximar ao gosto musical do destinatário e ao repertório barroco ibérico - demonstrado, por exemplo, pela opção pelo teclado partido, incomum na manufatura do mestre), não entenderíamos por que, afinal, o instrumento não foi apreciado no local onde era destinado e, consequentemente, por que acabou sendo colocado à venda e, em 1752, enviado para a nova diocese de Mariana e, além disso, por que seus tubos foram cortados no século XIX, tornando seu som menos agudo 50 .

Na preocupação com o restauro de um órgão, há, ainda algo a mais do que isso. O trecho citado a seguir foi extraído do livro The organ as a mirror of its time, uma publicação ligada aos trabalhos e projetos do Göteborg Organ Art Centre, uma instituição que batalha pela idéia de que, "Because it has always represented a rich collaboration of the music, art, architecture, handicraft and science of its day, the organ, more than any other instrument, continues to reflect the spirit of the day in which it was built"5l.

Ou seja, resgatar o patrimônio organístico significa não somente oferecer uma oportunidade de ressuscitar todo um universo musical, mas revelar aspectos técnicos, sociais e culturais de nossa história (como mostrado na resenha apresentada nesse mesmo livro que tem como objeto seis instrumentos construídos entre 1610 e 2000 no norte da Europa). O órgão oferece, por exemplo no caso do trabalho 
de Brescia ${ }^{52}$, o ponto de partida para um estudo de elementos arquitetônicos e decorativos do período barroco, entre península lbérica e Brasil.

Aqui estamos falando de um conceito que não é exclusivo do órgão, mas dos bens culturais como um todo:

Objetos artísticos guardam, em vários níveis, informações valiosas relacionadas à técnica, aos materiais, estilo, aspectos sociais, políiticos ou biográficos (tanto do produtor quanto do seu dono). Portanto, eles devem ser considerados, primeiro e acima de tudo, por meio de sua intenção original enquanto obra de arte. Alois Riegl relaciona o significado estético de uma obra ao seu valor artístico e a sua importância documental ao seu valor histórico ${ }^{53}$.

Nesta perspectiva, e dentre os instrumentos musicais, o órgão nos parece um caso exemplar, mas que, no Brasil, não é tratado como tal: como corretamente observado por Brescia, o Instituto do Patrimônio Histórico e Artístico Nacional (lphan) não prevê a proteção dos órgãos individualmente ${ }^{54}$, mas somente enquanto parte do conjunto de bens artísticos das igrejas onde ficam alocados ${ }^{55}$.

Por último, não se pode esquecer que o órgão, por ser um instrumento de grande porte e custoso, sempre foi sujeito a adequações mais ou menos profundas, porque sempre era visto em função de seu papel na liturgia le não como registro históricol e para evitar ter de adquirir novos instrumentos. Assim, quando chegam até nós, já acumularam "camadas de história" e efetivamente mais que um "espelho de seu tempo" constitui um testemunho cumulativo de todas as épocas pela quais ele transitou: "Any organ that has survived its own time [...] also has a story to tell about the times through which it has lived"56.

Isso abre uma questão de fundo na restauração dos órgãos, que é praticamente sempre decidir quais características dos instrumentos se quer privilegiar, com qual afinação, se e até que ponto reverter tais alterações e, portanto, em determinados casos, se e com que critérios cancelar certas marcas que o tempo deixou no instrumento.

Reflexões sobre o restauro de órgãos históricos:

os casos de Mariana e Tiradentes

Uma vez que se reconhece para o órgão de tubos o status de bem cultural no sentido mais amplo, isto é, cujo valor não está restrito unicamente à tarefa de produção de música para a adoração religiosa - mas ao mesmo tempo admitindo seu papel no âmbito da liturgia cristã -, instaura-se o problema de proporcionar condições de conservação e procedimentos adequados de recuperação/reativação/restauro, que levem em conta o fato, essencial de que ele é, antes de mais nada, um instrumento musical e, inevitavelmente, deve-se procurar que fazer com que ele possa desempenhar de sua função natural: isto é, ser tocado. E que toque regularmente, de forma otimizada, para a comunidade,
52. Ver Marco Aurélio Brescia (2008)

53. Ruskin (1996) apud Yacy-Ara Froner e Alessandra Rosado (2009, p. 5).

54. Ver Marco Aurélio Brescia (2008)

55. Assim, um órgão só pode ser restaurado com a aprovação da lei federal de incentivo à cultura se ele for tombado.

56. Cf. Kerala J. Snyder, (2002c, p. 339). 
57. Ver Teresa Cristina Toledo de Paula (2008).

58. Idem, p.244.

59. Idem, p. 245. tornando-se o centro de atividades culturais e o catalisador para o resgate de repertórios musicais e para a revitalização de toda uma sensibilidade estética.

Percebemos que, ao ver o órgão enquanto bem cultural a todos os efeitos, aplica-se a ele e à questão da sua conservação uma abordagem que tem fundamentos bastante bem definidos dentro de um debate em termos já claramente postos e que estão, por exemplo, sintetizados no trabalho de De Paula:

"A conservação tem como objetivo manter a integridade física e visual de um objeto, removendo-the e/ou acrescendo-the o mínimo de material. A restauração tem uma ordem diferente de prioridades: o aspecto visual ou funcional é predominante. Seu objetivo é recriar (no objeto), a aparência visual e física que se acredita tenha ele originalmente exibido". A diferença básica entre os dois modos de preservação, percebe-se, está no objetivo da ação: tratemos de compreender, portanto, o que se entende ou se imagina, hoje, por conservação de bens culturais ${ }^{57}$.

Deste artigo, citamos importantes considerações perfeitamente cabíveis ao caso dos órgãos históricos:

Podemos afirmar que, no lado ocidental do mundo, hoje, a atividade de conservação ainda se encontra embasada nas seguintes idéias: A. $\bigcirc$ fim do mito da reversibilidade; B. $\bigcirc$ respeito ao objeto, e interferência mínima; C. A necessidade de uma ética nos trabalhos; D. A importância da conservação preventiva ${ }^{58}$.

E, ainda:

A maior parte dos códigos, apesar de algumas diferenças regionais, considera ético o trabatho de conservação realizado sob os seguintes princípios básicos: 1. priorização dos valores documentais do objeto; 2 . pesquisa prévia e documentação exaustiva de qualquer intervenção; 3. ação de modo a fazer apenas o necessário; 4. uso de todo o conhecimento disponível sobre o assunto; 5 . uso, apenas, de materiais de qualidade comprovada; 6 . habilitação técnica e intelectual para desenvolver o trabalho que se pretende, não correndo riscos de nenhuma natureza. Esses princípios básicos norteadores, contudo, costumam ser interpretados de maneira diferente segundo as necessidades e os problemas específicos de cada tipologia de objeto. Isto significa que o conceito de mínimo necessário, por exemplo, será muito diferente se aplicado a um trem, a um vestido ou a um lustre. Acima de qualquer outra idéia, o trabalho ético pressupõe seriedade profissional, informação atualizada e bom senso ${ }^{59}$.

Sem querermos nos adentrar no exame das diversas escolas de pensamento sobre conservação e restauro, nas quais a idéia da reversão ao estado original do objeto não somente assume prioridades diferentes como pode ser, até, completamente descartada como abordagem à conservação, essas citações introduzem três princípios da maior importância, que defendemos na conservação do órgão de tubos. A dizer: 1) o respeito pela integridade, a função e a originalidade do objeto, ainda com a consciência da impossibilidade de uma completa reversão à sua condição primordial; 2) o papel vital da pesquisa, do levantamento de informações e do processo documental; 3) a atuação profissional que implica no 
compromisso com a habilitação técnica e intelectual e a atenção para a minimização dos riscos de prejuízo.

Desses critérios resultam alguns corolários, como o fato de que o zelo pela integridade do bem, quando genuíno, implica em assumir estratégias preventivas (discutidas mais adiante) e admissão da inevitabilidade, em qualquer processo de restauro, de uma postura transparente, da circulação de informações e da abertura de um confronto franco com a comunidade de especialistas sobre escolhas e decisões a serem tomadas, eventualmente, se necessário, envolvendo o lançar mão de recursos tecnológicos avançados. Nisso é exemplar a experiência do órgão germânico na igreja de Örgryte, em Göteborg (Suécia), pelo GoArt, na qual está presente, ainda que num projeto de reconstrução ex novo de um modelo de órgão clássico lou seja, algo completamente distinto de um processo de restauro de instrumentos históricos), a adesão a mais ou menos todas as recomendações vista acima: o anseio por um estilo e um som historicamente bem definidos, a fidelidade aos aspectos técnicos e artísticos originais, a busca do suporte científico, o compartilhamento de ideias, e a interação entre profissionais em todas as etapas do processo além da preocupação com o registro completo de informações ${ }^{60}$.

Cabe frisar que a própria experiência única do GoArt, construindo hoje um órgão usando métodos e técnicas do século XVII, influenciou de forma nítida as discussões a respeito do restauro de instrumentos antigos: embora cada situação deva ser tratada como um caso único, não havendo uma receita geral no restauro do órgão, precisam ser respeitados e compartilhados critérios e princípios bem definidos, discutidos, reconhecidos.

Somente a título de orientação, propomos (Figura 1) um esquema que mostra como deveria ser estruturado um processo de decisões sobre a recuperação de um órgão e onde a ênfase se coloca novamente em alguns dos pontos já citados: escrúpulo histórico e musicológico; respeito pela originalidade do instrumento; pesquisa e documentação; competência do time restaurador demonstrada; e conservação preventiva.

Ora, se as experiências européias se colocam como modelos importantes numa visão responsável da gestão do patrimônio organístico histórico, é óbvio que o cenário latino-americano apresenta um contexto distinto, com problemas e dificuldades próprias. E, nesse âmbito, o Brasil - com uma trajetória que difere bastante da dos nossos vizinhos, entre os quais Peru e México que dispõem de um corpus de instrumentos históricos comparável ao dos países europeus - tem uma colocação totalmente específica.

Hoje, os países latino-americanos também lutam para restaurar órgãos antigos e modernos, e um dos desdobramentos desse esforço foi a organização, em 2001, do congresso "La restauración de órganos históricos en Latinoamérica", na cidade de Oaxaca, México. O evento produziu uma carta chamada Carta de Oaxaca $^{61}$ (ver Anexo), que constitui um código de posturas assinado por um número grande de organistas e organeiros internacionais, preocupados com a preservação do patrimônio sonoro latino-americano. $O$ documento é dividido em três partes, a dizer a Introdução, que define o seu objetivo; o Regulamento Geral, identificando os atores suas funções e obrigações; e os Padrões de Procedimento. Essa terceira
60. Ver Kerala J. Snyder (2002a).

61. Ver o Anexo. 


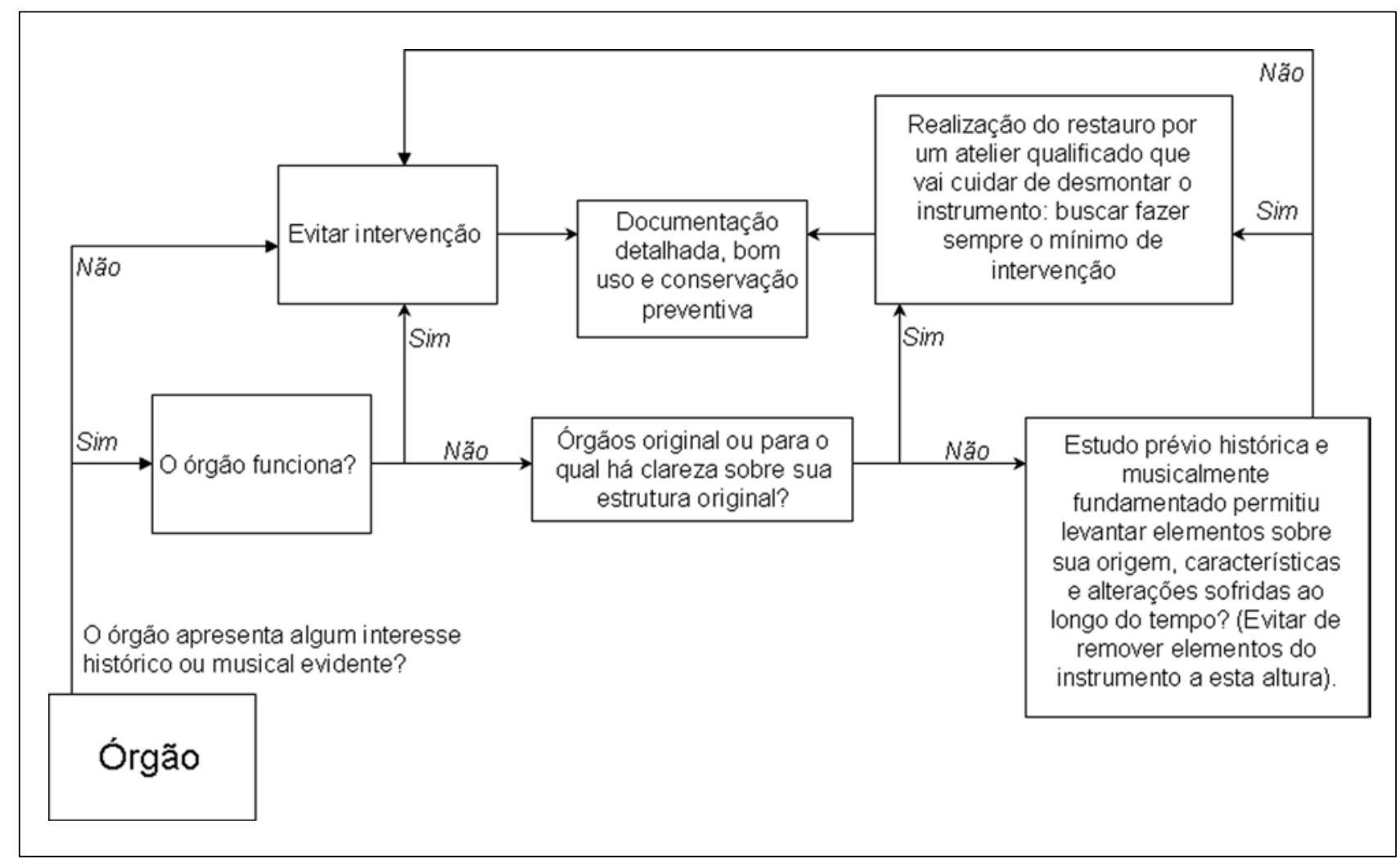

Figura 1 - Elisa Freixo e Andrea Cavicchioli. Esquema geral do fluxo de decisões envolvidas no restauro de um órgão de tubos, 2009.

seção traz uma apresentação pormenorizada dos princípios norteadores do restauro de órgãos e da série de etapas envolvidas na avaliação prévia do eventual trabalho e, também, na realização do restauro propriamente dito. Novamente, são reforçados, com insistência, aspectos já destacados em nossa discussão, como a pesquisa e a documentação (III, D, 2-3), o critério da intervenção mínima (III, D, 4-5), e o respeito ao estilo e características originais (III, D, 7-10), inclusive quanto aos materiais e métodos (III, A, 1 1-12). Realçamos, em particular, o enfoque dado à relação entre o instrumento e o seu entorno social e aos esforços a serem dedicados para identificar de antemão a inserção do instrumento restaurado na vida cultural da população, inclusive com a elaboração de um Plano de Utilização (Seção III, B). Por fim, o texto coloca justamente o princípio da subordinação do orçamento financeiro à adequação do restauro: nem sempre custos baixos são garantia de qualidade, porém um bom restauro, procurando via de regra minimizar as intervenções, dificilmente implica em despesas demasiadamente altas.

Nessa perspectiva, acreditamos serem experiências positivas os restauros dos órgãos barrocos de Mariana e de Tiradentes, que podem servir como modelos iniciais e fornecer contribuições importantes no movimento de resgate dos órgãos brasileiros (Figuras 2 e 3 ). 
primeiro deles deu-se em duas fases (1977-1984 e 1997-2002), num instrumento calado há 50 anos por conta da má manutenção e do ataque dos cupins. Karl Richter, em 1977, em visita ao Brasil, reconheceu nele a marca de Arp Schnitger e alavancou uma primeira recuperação parcial. Essa foi concebida, organizada e desenvolvida, inclusive criando um pool de empresas patrocinadoras, por Francisco Afonso Noronha (então presidente da Cemig) e pelo bispo dom Oscar de Oliveira, que entregaram a obra para a firma von Beckerath de Hamburgo, Alemanha. O processo, que nesta altura envolveu o restauro da caixa por especialistas do Instituto de Belas Artes de Belo Horizonte (Beatriz Coelho, fundadora do Cecor), foi completado na segunda fase, da qual têm-se maiores informações. Cabe dizer que o órgão apresentava um número muito grande de peças originais (tubos, teclado, puxadores), o que, inclusive, faz dele um exemplar bastante excepcional de órgão de manufatura Arp Schnitger, apesar de seu porte médio62.

Na fase de elaboração do projeto, a visão e compreensão de sua lógica por parte do dono do instrumento é sempre crucial: é necessário que seja entendida a importância do instrumento no contexto histórico e musical, sua unicidade e seu papel para a comunidade local, e seu posto na cultura da região, do país e da humanidade. Este tipo de consciência é nevrálgico, pois é da vontade do dono que, em primeira instância, emanam decisões cruciais para todo o processo, como a escolha do Comitê de Restauração - no caso, Elisa Freixo e alguns dos maiores conhecedores de organaria barroca alemã: Guy Bovet, Harald Vogel, Luigi Ferdinando Tagliavini e Cor Edskes.

A investigação prévia, realizada por esses especialistas, foi do tipo comparativo, inspirada no conhecimento acumulado sobre a organaria Arp Schnitger e na concepção barroca norte-alemã. Tal abordagem permitiv evidenciar e documentar (com fotos, descrições técnicas e filmes) toda uma série de informações com relação à manufatura, sonoridade e à colocação dos tubos nos someiros, à composição dos registros, aos mecanismos, ao sistema de alimentação de ar, e ao tipo e decoração da madeira. Dentre elas, destacou-se a clara indicação do corte das flautas - realizado no século XIX, a fim de adequar sua sonoridade ao gosto da época - e o descobrimento de alguns tubos não cortados, que forneceu um indício preciso sobre a altura original do som do instrumento. Ademais, foram identificadas as letras gravadas nos pés dos tubos pelo construtor, que contribuíram tanto para confirmação da autoria do órgão quanto para traçar a configuração original e as alterações sofridas ao longo do tempo.

Esse estudo preliminar conduziu a identificar as quatro ações que seriam objeto do restauro propriamente dito, sob o imperativo do menor número de mudanças:

- $\bigcirc$ restabelecimento da altura original do som, norteada pelas indicações fornecidas pelos tubos não cortados;

- A escolha de uma afinação antiga, embora a esta altura não estivesse ainda definida; 


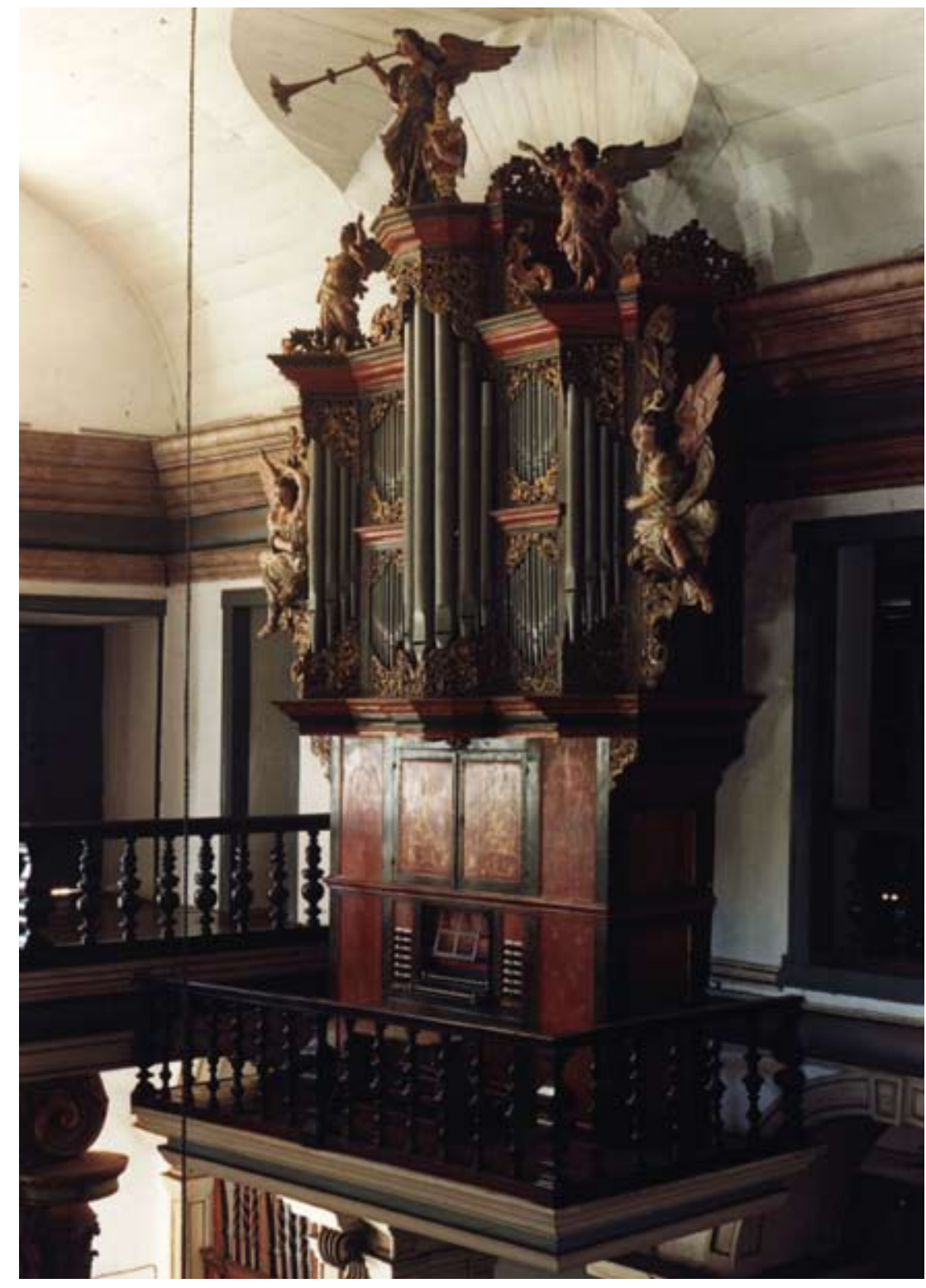

Figuras 2 e 3 - Fotografias dos órgãos Arp Schnitger de Mariana (esquerda) e Fernando Coutinho de Tiradentes (direita). Esses órgãos, conservados em igrejas de centros urbanos de menor importância na vida do país ao longo dos séculos XIX e XX, mantiveram sua estrutura original preservada, não somente na tubaria como na plástica da caixa sonora. Isso permite realizar atualmente uma série de constatações de interesse artístico e histórico, como: a escolha da estrutura tripartida ltípica da caixa hamburguesa, visível também no Arp Schnitger) na fachada do Fernando Coutinho, mostrando uma influência da estética alemã na região do norte de Portugal, onde o órgão foi construído; a presença de alguns elementos decorativos típicos do órgão ibérico no Arp Schnitger (os cinco anjos e os sofisticados motivos chineses), que, ao que tudo indica, foram acrescentados no instrumento em Portugal antes de sua transferência para o Brasil, possivelmente para harmonizar sua aparência com o contexto artístico do local que o abrigava; a pintura rococó e a talha da caixa do Fernando Coutinho feitas em Tiradentes pelos artistas mineiros Manuel Victor de Jesus e Antônio Teixeira Vianna seguindo o gosto da época. Apesar das semelhanças externas, os dois instrumentos são profundamente diferentes na concepção do som e na organização interna dos tubos. Fotografias de Eduardo Troppia (Arp Schnitger) e Marco Aurélio Brescia (Fernando Coutinho). 


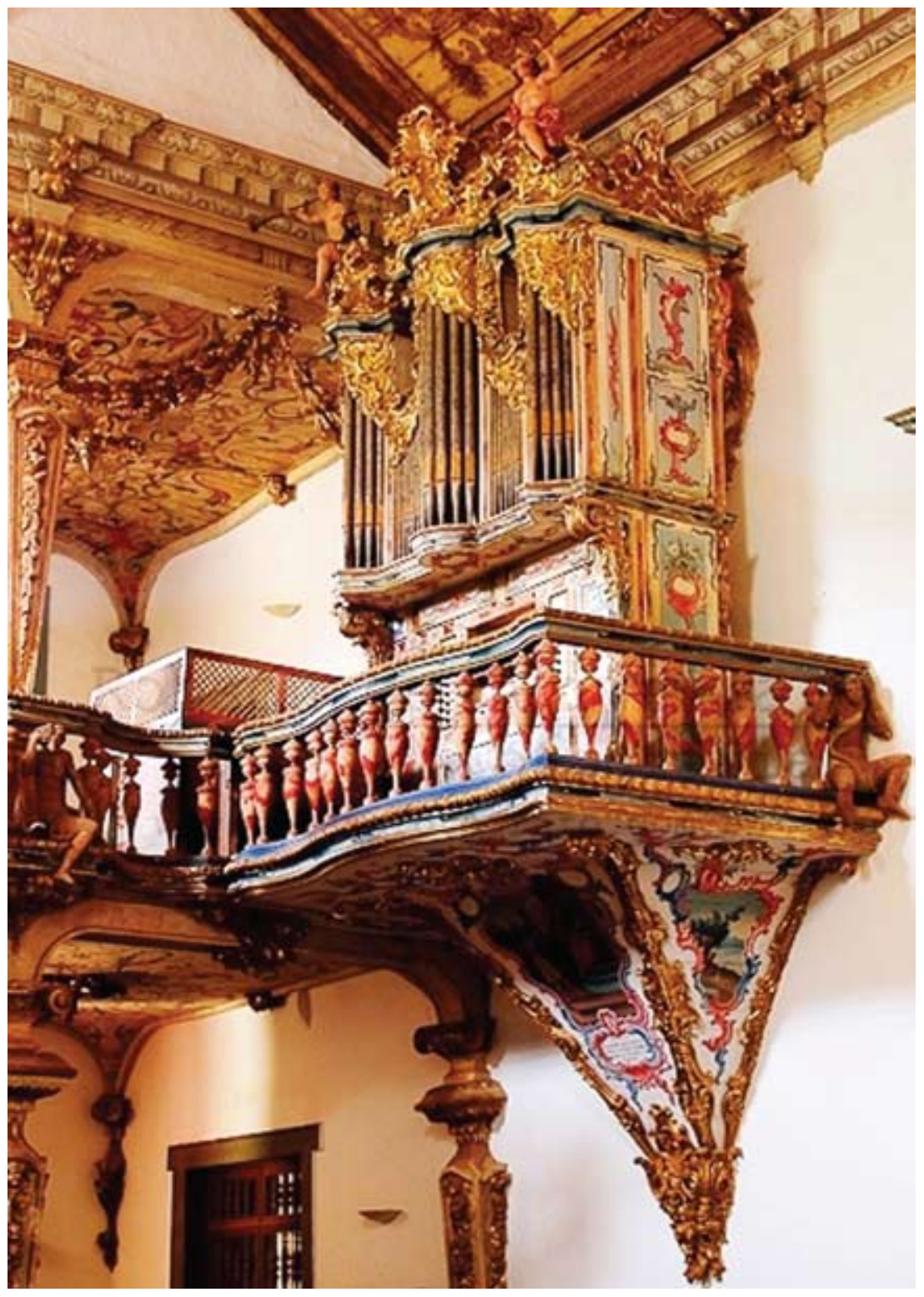

- A reconstrução dos foles, imprescindível em função da alimentação insuficiente;

- A reconstrução parcial e realocação dos registros de lingueta, claramente instalados fora do lugar.

A escolha da firma restauradora baseou-se no critério da competência para instrumentos desta fatura: a oferta foi feita a Bernhard Edskes, tido em alta consideração nesta área, que aceitou. A desmontagem e envio do instrumento para a Suíça foram feito seguindo critérios de cautela (numeração, embalagem segura). $\bigcirc$ restauro foi antecedido por um segundo nível de vistoria, envolvendo 
63. Ver <www.orgaodase. com.br>.

64. Ver $<$ www.arpschnitger. $\mathrm{nl}>$ a realização de uma endoscopia dos tubos, que confirmou a presença das marcas identificadoras de cada flauta especularmente impressas no seu lado interno. Investigações como esta e a disponibilidade, na oficina Edkes, dos mais avançados conhecimentos em matéria de tratamento e modelagem do metal na oficina Arp Schnitger, mostram que a competência do restaurador e o deslocamento de parte do instrumento para a Europa foi imperativo no seu restauro.

Com relação aos foles, foi necessária a construção de dispositivo novo, - que se deu através da realização de uma réplica baseada em modelos usados, segundo o que se sabe, em órgãos análogo do mesmo autor.

Remontado o instrumento em Mariana, a última parte do restauro foi a afinação, para a qual o Comitê tinha evidentemente optado por uma modalidade antiga, embora fosse de fato necessário decidir qual delas, entre as várias opções. Para isso, novamente se recorreu ao critério do consenso da comunidade musical especializada e, consequentemente, realizou-se uma consulta aberta, que deveria resultar na apresentação de propostas justificadas.

projeto não sofreu entraves burocráticos significativos e, no setor privado, alavancou patrocínios com certa facilidade, em função essencialmente do consenso de intenções que se estabeleceu entre as partes envolvidas; da transparência do processo e seu caráter internacional; e do embasamento técnico e científico do trabalho, que antecipou a elaboração do projeto submetido ao Iphan (MinC). Isso novamente nos leva a enfatizar como o restauro de um órgão implica num trabalho de inúmeras facetas, com esforços requerendo as mais diversas habilidades, mas de todo modo um trabalho bem integrado de equipe. Ainda, no entanto, por rigor de crônica, cabe destacar os problemas alfandegários enfrentados por conta da situação inusitada de objetos de arte saírem do país e retornarem num estado alterado, ocorrência que a lei brasileira não prevê: uma falha que, dadas as circunstâncias, o legislador precisa remediar.

A reinauguração do órgão marcou o início de uma série intensa e diversificada de atividades educacionais e culturais, destacando-se, entre elas: ciclos regulares de concertos (nos primeiros tempos, 1 vez por mês, sucessivamente 2 vezes por semana), totalizando cerca de 2120 apresentações até o fim de 2009; constante participação nas celebrações litúrgicas; cursos para organistas; gravação de discos de vinil e CDs; programas radiofônicos e televisivos nacionais e internacionais; pesquisas científicas e musicais, com visita de organistas e estudiosos (restauradores e conservadores) do mundo inteiro. Hoje, o órgão da Sé de Mariana tem seu próprio site de divulgação na internet ${ }^{63}$, com elementos sobre sua origem e história, e está incorporado na lista de instrumentos de fatura Arp Schnitger ${ }^{64}$. Seus concertos de música são um dos principais atrativos turísticos e culturais da cidade e de toda a região histórica de Minas Gerais.

Vários dos aspectos envolvidos na restauração do órgão de Mariana no início deste novo século - uma operação de fato não restrita à simples reativação do instrumento - surgiram novamente na recuperação do órgão de Tiradentes, que se beneficiou com a experiência anterior, num processo mais ágil embora igualmente rigoroso. 
O desejo da restauração do instrumento surgiu inicialmente a partir do levantamento do estado dos órgãos barrocos feito por Bovet e Freixo ${ }^{65}$ e firmou-se, em seguida, por ocasionar a obra de restauro da igreja de Santo Antônio, onde ele está abrigado. Mais uma vez, a vontade e a disposição - e a abertura dos donos do órgão, da comunidade no entorno e do lphan de Tiradentes - foram determinantes tanto na decisão inicial como na elaboração de um projeto bem fundamentado por dados históricos e na própria fase de realização do trabalho, que, afinal, foi coordenado por um Comitê de Restauração, composto pelo pároco da igreja de Santo Antônio, Olinto Rodrigues Filho (representante local do Iphan), Elisa Freixo, Gustavo Eros da Conceição, Guy Bovet, o luthier Abel Vargas e, ainda, com o suporte de consultores externos, como Gerhard Doderer e Cristina Banegas.

A pesquisa realizada pelo Comitê revelou elementos importantes, confirmando a autoria do órgão, em particular a descoberta de papéis antigos, colados no interior do instrumento, trazendo a assinatura de Simão Fernando Coutinho: ao que parece, cartas do organeiro, que foram reaproveitados durante a construção do órgão. Já o exame técnico da tubaria, praticamente completa, não mostrou nenhuma surpresa em relação à composição e ao conceito do órgão, tendo sido fácil evidenciar alguns problemas de trocas de posição e, como no caso de Mariana, o corte das flautas realizado no século XIX. Além disso, identificaram-se problemas de ataque por cupins e couro degradado.

A concorrência para escolha da firma restauradora envolveu 3 oficinas, sendo que a escolhida foi a firma de Gerhard Grenzing, aquela cujo projeto trouxe a apresentação mais completa e propôs as escolhas organologicamente mais consequentes, embora coincidindo com o orçamento mais custoso. A autoridade dessa firma, em matéria de órgãos ibéricos, emana da experiência, da competência técnica e do profundo embasamento filosófico de seu mentor, da qual se pode ter uma clara noção pelos artigos, entrevistas e descrições detalhadas de projetos realizados, dos quais extraímos, a título exemplificativo, declarações que denotam a adesão do mestre às teses defendidas em vários pontos deste artigo:

For us, an historical organ is like a defenseless living being asking us to respect it as we try to preserve it. We come face to face with this challenge each and every time and try and treat each case on its own terms, as if it were the very first time.[...] Today, the quality of a restoration is judged by the restorer's ability to preserve the instrument. This is an enormous responsibility that requires the restorer to be on par with the instrument he is asked to restore and to possess the necessary experience, carry out research and act with all due prudence and respect. [...] An instrument's musicality, it original spirit, is very, very fragile; that's why undertaking a task of this nature is such a delicate matter ${ }^{66}$.

Como no caso de Mariana, todo o restauro foi completamente documentado e executado com o devido cuidado para com as peças originais, que, quando substituídas, foram adequadamente guardadas para fins documentais.
65. Ver Guy Bovet e Elisa Freixo (1987).

66. Ver <www.grenzing com>. 
67. Ver Yacy-Ara Froner e Alessandra Rosado (2008).

68. Garry Thomson (1986).

69. Ibidem. E, também, Luiz A. C. Souza (1994).
Um diferencial no restauro do órgão de Tiradentes com relação a Mariana foi o inclusão de uma empresa de consultoria e gestão de projetos culturais, que facilitou a articulação entre as partes envolvidas (Comitê Restaurador e seus componentes, Iphan/MinC, Associação Amigos de Tiradentes e Prefeitura da Cidade, patrocinadores, restaurador, autoridades alfandegárias), numa ação em que novamente competência, história e seriedade foram fundamentais para sua inserção no projeto.

Com relação à afinação do instrumento, não havendo na tubaria sinais da escolha feita pelo autor, optou-se por uma solução comum em Portugal na segunda metade do século XVIII (mesotônica ligeiramente alterada), reversível e, portanto, ainda sujeita a alterações, caso pesquisas futuras apontem para a oportunidade de adaptações nesse sentido.

A partir da reativação do órgão, pôde-se dar vida a um conjunto de atividades educacionais e de valorização da música barroca, mais ou menos na mesma linha que em Mariana, embora o órgão ainda esteja em processo de construção de seu espaço na agenda cultural da cidade.

Conservação preventiva dos órgãos

A idéia de conservação preventiva começa a se impor com força, como elemento de conservação de bens culturais nas décadas de 1980 e 1990. Froner e Rosado ${ }^{67}$ atribuem um peso preponderante para o fortalecimento dessa tendência à divulgação das teorias de Garry Thomson, em The Museum Environmentô8. $\bigcirc$ livro reúne e sistematiza informações disponíveis sobre as relações entre os diversos fatores ambientais, como temperatura, umidade, radiação luminosa e polventes atmosféricos, e a degradação dos materiais e, assim, estabelece as bases para estratégias de contenção dos processos degenerativos, mediante controles climáticos e de qualidade do $a^{69}$. Trata-se essencialmente de aplicar o princípio pelo qual é melhor antecipar o risco de dano físico (aos materiais) associado às características do microambiente em que o bem de interesse artístico está alojado e predispor de medidas adequadas para reduzir tal risco. As alterações físicas e químicas, evidentemente, por princípio nunca podem ser impedidas, mas estudos aprofundados (sobre as complexas interações entre os componentes moleculares dos materiais, as reações químicas às quais estão sujeitos e a interferência de agentes externos) podem fornecer orientações para um controle desses agentes, que resulte numa redução significativa da velocidade com que tais reações ocorrem e estender o tempo de vida dos artefatos.

Nesta perspectiva, a conservação de bens culturais pode ser abordada combinado o monitoramento ambiental com a adoção de práticas de gestão dos espaços de conservação, ou, dito com as palavras de May Cassar:

The key to the survival of museum collections is a stable indoor environment [...] Preventive conservation which should be the responsibility of all museums has two important aspects: The 
technical dealing with the monitoring and controlling the museum environment, and the organizational involving all staff working in a museum ${ }^{70}$.

Ou seja, prevenir a degradação envolve um primeiro momento de avaliação de risco e um segundo passo de organização do quadro operacional do museu, ou de qualquer outro espaço de conservação, para conciliar a necessidade da preservação, mediante o controle ambiental, com o objetivo do usufruto e apreciação do bem cultural. Uma tarefa não trivial, caso se pense que, quase sempre, os edifícios envolvidos foram construídos para outras finalidades e privilegiam exigências de estética ou de conforto para as pessoas ${ }^{71}$ : uma colocação particularmente pertinente, no caso dos órgãos, geralmente instalados em igrejas - razão pela qual, hoje, em vários paises, busca-se adotar medidas para uma climatização adequada para as congregações, mas também não nociva às obras de $\operatorname{arte}^{72}$.

Existe, neste contexto, uma linha de pensamento que, numa abordagem de conservação preventiva, sugere a busca sinais antecipadores (early warnings) de danos futuros nos objetos a serem protegidos. Trata-se de desenvolver técnicas que permitam evidenciar alterações físicas (por exemplo, microrrachaduras) ou químicas (alterações em nível molecular) quando estas estão ocorrendo ainda numa escala microscópica e descobrir as causas no ambiente circundante, conceito inicialmente discutido por van der Brink, Eijkel e Bonn ${ }^{73}$. Tal tipo de detecção apresenta, intrinsecamente, a desvantagem, ao menos em tese, de depender da possibilidade de estudar os próprios objetos artísticos com técnicas sofisticas e necessariamente não destrutivas, o que, na prática, é evidentemente impossível e implicou no desenvolvimento de abordagens de compromisso, a maioria das quais recentemente revisadas ${ }^{74}$.

Cabe dizer que a conservação preventiva não quer se impor como alternativa à restauração e que isso ainda deixa em aberto a discussão geral sobre a conveniência de restaurar obras já danificas ou submetê-las a restauro. No entanto, Bernardi observa que: "It is not enough to use good techniques for restoration in order to preserve a precious work of art for the future, as each work of art can only be submitted to a severely limited number of 'restorations'"75.

Ações preventivas, claramente, tornam-se mais complexas à medida que a variedade de artefatos e materiais abrigados pelos museus aumenta, levando a abordagens elaboradas como as mencionadas por Waller ${ }^{76}$. Essa observação é válida também para objetos culturais individuais compósitos, isto é, constituídos, por sua natureza, de materiais diversos, com exigências distintas, quando não conflitantes. E o órgão se coloca exatamente nessa situação, com sua estrutura de madeiras, metais e couro 77 .

Recomendações baseadas simplesmente no bom senso são uma boa ajuda, mas nem sempre completamente adequadas. Considere-se, por exemplo, o documento encontrado dentro de um antigo órgão de São Paulo, que instrui os proprietários e usuários com relação à manutenção do instrumento:

Instruções para manutenção do órgão. No corpo do órgão [Moller (1930), Igreja Presbiteriana Unida de São Paulo] havia um papel colado, em inglês, datado de 8 de setembro de
70. Ver capa em May Cassar (1995).

71. Ver Adriana Bernardi (1990).

72. Ver Dario Camuffo et al. (2007).

73. Ver O. F van der Brink, G. B Eijkel e J. J. Bonn (2000).

74. Ver Mauro Bacci et al. (2008).

75. Cf. Adriana Bernardi (1990, p. 169).

76. Ver Robert Waller (1994)

77. Nessa lista, podemos incluir outros, como marfim, por exemplo, ou ainda pedra sabão, usada no fole do órgão de Mariana. 
78. Cf. Dorotéa Kerr, (2001, p. 195).

79. Ver Carl Johan Bergsten et al. (2003-2005).

80. Ver Carl Johan Bergsten et al. (2008).

81. Ver Ver Tom Clarke (2004); Annika Niklasson (2007); Annika Niklasson et al. (2008); Cristina Chiavari et al. (2008).
1930, com instruções para sua manutenção. "[...] umidade: umidade é muito prejudicial. Portanto, é extremamente essencial que o órgão seja sempre mantido todo seco e bem ventilado. [...]. Poeira: os limpadores da igreja devem ser instruídos a tomarem precaução para levantar o mínimo de poeira possível. [...] Caixa expressiva: é recomendável manter as venezianas das caixas expressivas abertas, mesmo quando o órgão não está em uso, para manter a temperatura igual em todo o instrumento. Afinação e temperatura: durante o inverno, quando o órgão tiver que ser afinado, a igreja deve estar aquecida na mesma temperatura em que o órgão será usado durante os cultos, caso contrário à afinação não será satisfatória. Entretanto, igreja e órgão nunca devem em tempo algum ser aquecidos acima de 75 graus [presumivelmente, Fahrenheit, ou seja, aproximadamente $24^{\circ} \mathrm{C}$ ]. Será extremamente prejudicial se uma temperatura além dessa for levada para o interior do órgão"78.

De um modo geral são instruções compatíveis com as propriedades dos materiais, mas, num país tropical, a questão da umidade relativa e da temperatura deve ser vista de uma forma distinta daquela dos paises de clima temperado: não somente não faz sentido falar em aquecimento do local ou qualquer outro tipo de controle térmico, como é ilógico esperar que o ambiente possa ser mantido em baixas condições de umidade. Hoje, como principal medida de conservação de bens sensíveis a efeitos de temperatura e umidade, os pesquisadores recomendam limitar, em curtas escalas de tempo, as flutuações desses fatores, quando não há possibilidade de estabilizá-los em níveis desejados ótimos. De qualquer forma, não há dúvida da constante necessidade de investigações de cunho científico neste âmbito.

Nos últimos anos, dois grandes projetos, fomentados pela Comissão Européia no âmbito do $5^{\text {th }}$ e do $6^{\text {th }}$ Framework Programmes, foram especificamente direcionados para a obtenção de maior conhecimento dos processos associados ao desgaste físico dos órgãos e para o desenvolvimento de técnicas de conservação preventiva, em particular com relação à corrosão dos tubos de chumbo: Collapse ${ }^{79}$ e Sensorgan ${ }^{80}$. Ambos foram coordenados pelo já mencionado GoART e envolveram centros de pesquisas na Inglaterra, Itália, Polônia, Suécia, Alemanha, Dinamarca e no Brasil.

primeiro programa permitiu recolher um vasto conjunto de dados sobre a corrosão de órgãos antigos e suas prováveis causas. Mediante monitoramentos atmosféricos no ambiente de sete igrejas (interna e externamente a seus respectivos órgãos históricos) e a análise química e morfológica dos materiais e dos produtos de corrosão, bem como a realização de ensaios laboratoriais em condições controladas dentro de câmaras climáticas, foi possível chegar detectar que: ${ }^{81}$

- A corrosão dos tubos de chumbo ou de ligas ricas em chumbo está correlacionada à presença de gases de ácidos orgânicos lácido acético e ácido fórmicol e à composição química dos metais.

- O sistema de alimentação dos órgãos é a principal fonte de emissão desses gases, produzidos durante a decomposição (hidrólise) de partes fibrosas (hemicelulose) da madeira. Algumas colas modernas a base de polivinilacetato também são fontes não desprezíveis de 
substancias nocivas. Observou-se que, muitas vezes, a introdução de peças de madeira nova ou o uso de cola em restauros de órgão acarretam um aumento na concentração atmosférica de tais espécies e, consequentemente, um maior risco de impacto. Algumas madeiras, como pinho, carvalho e pau-brasil são particularmente propensas à emissão de ácidos orgânicos voláteis ${ }^{82}$.

- A corrosão ocorre pela formação de carbonatos de chumbo, hidrocerrusita e cerrusita, após algumas etapas químicas intermediárias: esses compostos são conhecidos no meio artístico como branco de chumbo, muito usado no passado como pigmento de tintas e produzido justamente pela imersão de placas de chumbo em vinagre, cujo principal componente é o ácido acético. $O$ carbonato de chumbo é um sólido poroso, com escassa resistência mecânica, que esfarela facilmente e, portanto, leva a uma progressiva destruição do tubo.

- A corrosão do tubo depende dramaticamente da sua composição e, em particular, da presença de porcentagens até pequenas de estanho: quanto maior, menor a probabilidade de corrosão.

- A existência de indícios, no interior dos tubos, de ar úmido e de fenômenos de condensação.

Com base no acúmulo de informações científicas obtidas pelo projeto Collapse, deu-se início, com o Sensorgan, a uma fase de desenvolvimento de ferramentas de diagnósticos baseados nas condições ambientais em torno dos órgãos ${ }^{83}$. Hoje, graças aos resultados desse trabalho, é possível poder estabelecer in situ se, no seu conjunto, as condições climáticas, a composição atmosférica, o uso do instrumento e os processos de gestão do espaço no qual um órgão está abrigado são, ou não, propícias ao surgimento de problemas de corrosão dos tubos ou desgaste das demais partes do instrumento, indicando assim possíveis estratégias de mitigação ou contenção.

Numa operação em conjunto entre os parceiros do Sensorgan, gradativamente tais técnicas estão sendo aplicadas para sondar os ambientes e os microambientes (por exemplo, diretamente no interior dos pés dos tubos) e avaliar o risco de dano ao órgão de Mariana e ao de Tiradentes, bem como a instrumentos nas igrejas de St. Botolph without Aldgate (Londres), Santo André Apóstolo (Olkusz, Polônia), e na lgreja Nova de Orgryte (Gotemburgo, Suécia).

Em Mariana, a primeira etapa do processo consistiu no monitoramento de temperatura e umidade relativa por doze meses, entre 2007 e 2008, ilustrado nas Figuras 4 e 5.

Os dados permitiram fazer uma avaliação bastante completa do microclima, dentro e fora do instrumento, que pode ser resumida nos seguintes pontos:

- As médias da temperatura e da umidade relativa registradas dentro da igreja (Figura 4), cruzadas com os dados meteorológicos da
82. Ver Maria Risholm-Sundman et al. (1998).

83. Ver Carl Johan Bergsten et al. (2008). 


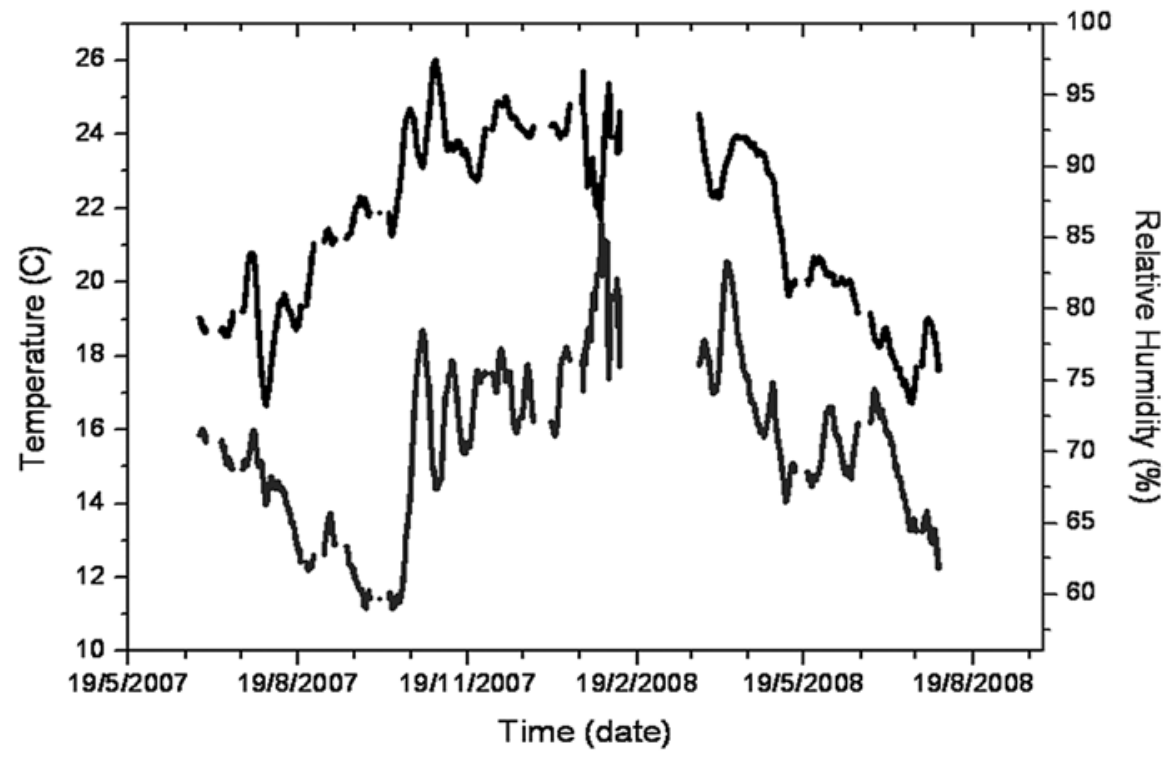

Figura 4 - Andrea Cavicchioli. Valores médios da temperatura e da umidade relativa medidos na sala do fole durante o período de monitoramento, 2009.

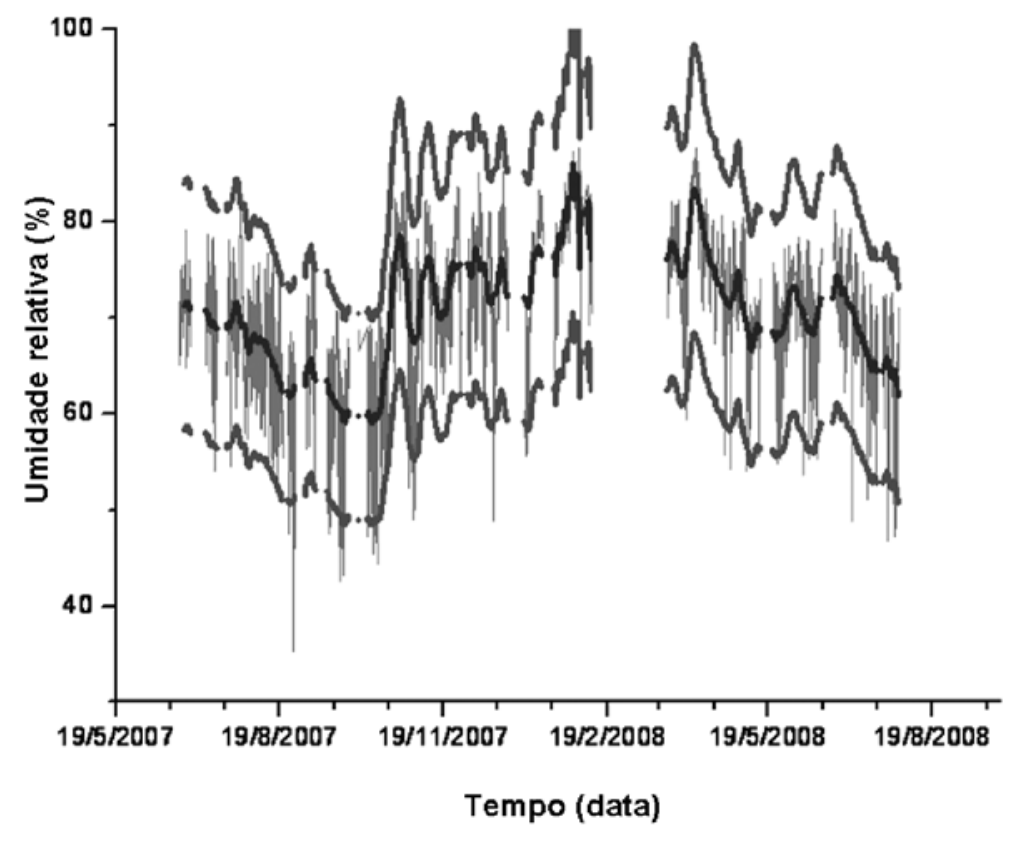

Figura 5 - Andrea Cavicchioli. Flutuações da umidade relativa na sala do fole durante o período (linha mais fina) e limites de segurança num intervalo de $\pm 18 \%$ (cinza claro) ao redor da média (cinza escuro), 2009. 
região, permitem identificar claramente um regime climático diretamente influenciado pelas condições externas, com duas grandes estações: uma estação úmida (outubro a junho) e uma estação seca (julho a setembro), sendo a transição de uma para a outra nitidamente afetada pela ocorrência de precipitações chuvosas e incidência de mais, ou menos, radiação solar.

- As flutuações do clima da região refletem-se diretamente nas variações internas, onde são, porém, menos intensas. Já no interior do órgão, tais variações são ligeiramente menos intensas do que na sala do fole.

- No caso da umidade relativa, destaca-se que, na atmosfera da igreja, nunca são registradas condições de 100\% de umidade relativa. No entanto, as superfícies sólidas podem apresentar, em certos casos, temperaturas mais baixas que a do ar e isso pode causar fenômenos de condensação. $\bigcirc$ monitoramento permitiu verificar que o perigo é mais alto nos períodos menos quentes (agosto) ou mais úmidos (fevereiro).

- Uma avaliação dentro e fora da igreja das temperaturas e umidades relativas reais (não médias) indicam que os horários com as maiores diferenças entre ambiente interno e externo são, tipicamente, entre oh e $7 \mathrm{~h}$ e entre $15 \mathrm{~h}$ e $16 \mathrm{~h}$ (temperatura) e entre $6 \mathrm{~h}$ e $8 \mathrm{~h}$ e entre $15 \mathrm{~h}$ e $16 \mathrm{~h}$ (umidade relativa). Para evitar alterações drásticas no clima interno, o ideal é evitar trocas de ar nesses horários e favorecer os momentos em que as diferenças são mínimas lao redor das $12 \mathrm{~h}$ e entre $20 \mathrm{~h}$ e $23 \mathrm{~h}$ ).

- A Figura 5 aponta a frequência de variações súbitas (num período de poucas horas) e elevadas (>18\%) na umidade relativa. Como podem causar tensões mecânicas repentinas sem que o instrumento tenha tempo suficiente para adaptar-se internamente, tais eventos são perigosos; eles tendem a ser mais frequentes e intensos na parte externa do órgão e no período seco (julho e agosto).

- Com relação à quantidade total de água (razão de mistura) presente na atmosfera, foi possível evidenciar que sempre há uma quantidade maior dentro da igreja e do órgão do que na atmosfera externa, o que pode ser interpretado com base na hipótese de haver uma fonte de água no ambiente interno (possivelmente as próprias paredes da igreja que atuam como "esponjas" que absorvem água de fora e a jogam para dentro).

A combinação de umidades e temperatura altas (comparativamente, pelo menos, às situações encontradas nos climas temperados da Europal é tradicionalmente enxergada como um elemento que favorece a degradação dos materiais artísticos e, certamente, um fator que propicia a atividade biológica, ou seja, o desenvolvimento de fungos e de pragas. No entanto, trata-se de um fato 
que não apresenta solução: o clima da região é esse e tem de ser aceito, especialmente porque a igreja não é um edifício que possa ter sua arquitetura alterada para modificar o microclima. Por outro lado, no caso da madeira e do couro, são eles os materiais que sofrem mais com variações intensas da umidade do que com um teor elevado dela - embora, é claro, eles possam vir a ser prejudicados pelo desenvolvimento excessivo de pragas. Assim, do ponto de vista dessas partes do órgão, parece ser mais importante, viável e efetivo focar na minimização das flutuações da umidade relativa e da temperatura como medida de preservação. Os dados do monitoramento indicam que a tarefa é mais importante no inverno (julho a setembro) quando, com a ausência de chuva e a ocorrência de dias bastante secos e noites relativamente úmidas, são mais frequentes situações de desequilíbrio. É nestes momentos que madeira e couro podem sofrer estresses mecânicos drásticos, decorrentes de uma queda rápida da umidade relativa na atmosfera, resultando em perda de água e encolhimento. Este tipo de fenômeno tende a criar, nesses materiais, microfissuras que, por sua vez, constituem o preâmbulo de futuras rachaduras macroscópicas.

Cabe lembrar que a umidade relativa é uma grandeza que mede a capacidade da atmosfera de receber vapor de água: quanto menor ela for, mais os objetos perderão água, ressecando; e tal parâmetro depende tanto da quantidade total de água presente na atmosfera (razão de mistura da água) como da temperatura. Assim, o que acontece no inverno está em parte relacionado à diminuição total de água no ar (chove menos) e, em parte, às temperaturas bastante elevadas durante o dia (dia secos são mais quentes porque a radiação solar penetra mais). Por outro lado, as noites invernais tendem a sofrer quedas marcantes de temperatura, causando um aumento súbito na umidade relativa. Assim, em tese, há duas possibilidades para limitar a queda da umidade relativa dentro da igreja e buscar manter um microclima estável: aumentar a quantidade de água na atmosfera ou evitar o aumento da temperatura. A primeira opção é mais arriscada porque um aumento da quantidade absoluta de umidade na atmosfera pode acarretar condensação nas superfícies frias (por exemplo, os metais). Neste sentido, a prática de introduzir recipientes de água em contato com o ar, adotada em certos casos para contornar o excesso de secura no ar, é pouco eficaz e o uso de umidificadores comerciais é altamente desaconselhável, pois quase inevitavelmente redundam em paredes encharcadas e maior desenvolvimento de fungos, podendo acelerar processos de corrosão. Já a manutenção de um ambiente com temperatura controlada parece uma abordagem mais segura e eficiente. Isso pode ser obtido, especialmente no caso da Catedral de Mariana, limitando a entrada direta de radiação solar pelas portas e, sobretudo, pelas janelas. Em alguns casos, tem-se conseguido isso com o auxílio de filmes protetores adequados aplicados diretamente sobre os vidros. A troca de ar com o ambiente externo (ventilação) deve ser restrita aos horários em que a diferença entre temperatura e umidade relativa entre o interior e o exterior da igreja é mínimo, isto é nas primeiras horas da manhã (9h-10h) e no começo da noite (19h-20h).

Em Tiradentes, a avaliação climática ainda se encontra em andamento. No entanto, está sendo usado, no órgão Fernando Coutinho daquela cidade, um 
sensor, desenvolvido durante o Sensorgan, que permite avaliar a propensão à corrosão do chumbo de um determinado microambiente: quanto mais intensa a resposta do sensor, mais alto o risco de corrosão associado àquele microambiente ${ }^{84}$. Os resultados são obtidos comparando a resposta do sensor exposto dentro do órgão com dois sensores colocados respectivamente numa câmara climática apresentando elevada contaminação por ácidos orgânicos $165 \%$ de umidade relativa) e numa câmara em condições controle, a 35 \% de umidade relativa, focando, nos primeiros dias de exposição, o comportamento do sensor.

O ensaio mostra claramente (Figura 6) que a atmosfera dentro do órgão acarreta no sensor uma resposta com a mesma intensidade que o sensor na câmara contaminada - o que indica um elevado risco de degradação para os tubos apesar de toda a madeira já ser praticamente envelhecida. Experimento análogo está sendo conduzido internamente, na base de alguns tubos, para estabelecer se as mesmas condições se verificam nessa região do instrumento. Mas ainda, devemos ressaltar que a constatação do ótimo estado de praticamente todas as flautas do órgão sugere que elas, por características intrínsecas, apresentam resistência ao ataque dos ácidos orgânicos. Em função disso, maiores investigações devem ser empreendidas para melhor caracterizar as propriedades químicas dos tubos, para uma definição do efetivo grau de risco de dano e de um adequado plano de gestão ambiental do espaço.

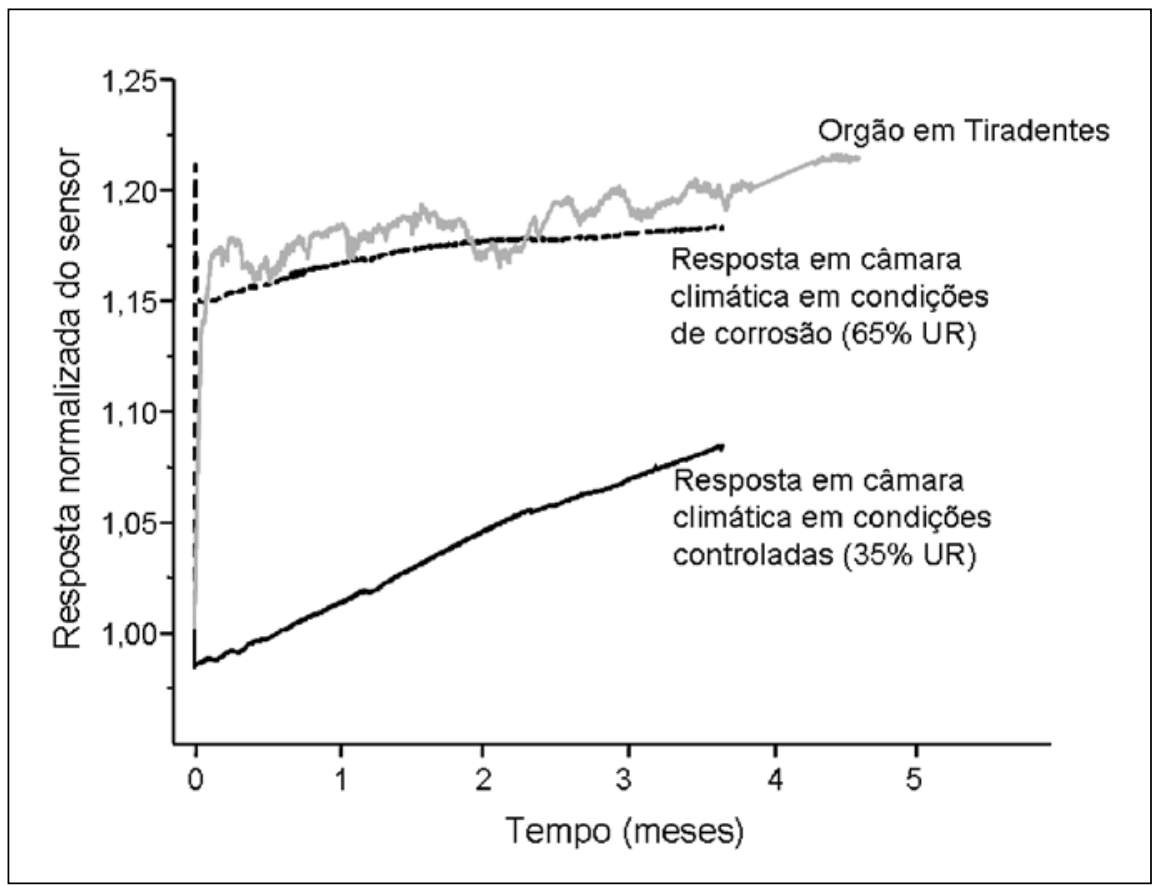

Figura 6 - Andrea Cavicchioli. Resposta de sensor, 2009. 
órgão é um instrumento muito complexo, talvez o mais complexo de todos. Sua construção e manutenção exigem conhecimentos de marcenaria e madeira, metalurgia e solda, acústica e música, arquitetura e estética, além de uma boa familiaridade com repertório organístico. Os organeiros devem ter, ainda, uma grande capacidade de negociação com os proprietários dos instrumentos e com quem os utiliza, de forma a ter capacidade de atender as demandas possíveis e mostrar o ponto de vista da preservação da originalidade dos órgãos e, portanto, evitar sua destruição através de reformas mutiladoras.

No artigo, mostramos como, no século XX, os órgãos brasileiros foram vitimados, de um lado, por um período de abandono e perdas; e, de outro, por reparos mal feitos ou mal planejados, resultando hoje numa situação em que poucos instrumentos estão em boas condições de uso.

Situados em sua maior parte em igrejas, tendo alguns exemplares instalados em escolas de música ou teatros, os órgãos nem sempre são compreendidos como instrumentos musicais únicos, que devem ser tratados como tal e que requerem cuidados específicos: nem sempre uma pessoa especializada em órgãos franceses do século XIX vai estará capacitada a restaurar um órgão colonial brasileiro do século XVIII. Entre nós, tais questões ainda não estão bem postas e, nesse sentido, há falta de conhecimento de todos os envolvidos, fazendo com que pessoas despreparadas - técnicos em piano ou em harmônio, por exemplo - sejam chamados para restaurar órgãos tubulares, e os resultados desastrosos dessas interferências têm provocado a destruição de parte significativa do nosso patrimônio musical sonoro.

Acrescenta-se que, apesar de tradicionalmente serem considerados instrumentos históricos apenas os exemplares com mais de 50 anos de vida, todos os instrumentos, tanto os antigos como os recentes, deveriam ser considerados objetos dignos de respeito, pois cada época deixou sua marca, suas características e suas necessidades nos instrumentos que produziu, e a atual fase também tem o direito de deixar seu legado.

Ainda não temos, no Brasil, normas específicas a respeito da preservação de instrumentos musicais. A profissão de organeiro não é regulamentada, sendo colocada na categoria geral de Artesanato. Existe um sindicato de fabricantes de instrumentos musicais que engloba a categoria do pequeno luthier, aquele que trabalha artesanalmente. Ao mesmo tempo, constatamos que as diversas atividades realizadas manualmente também carecem de regulamentação. A arte organária é um ofício que exige um aprendizado de técnicas específicas, através da convivência diária com mestres organeiros. A formação de um organeiro-mestre dura pelo menos 10 anos e, em países onde a profissão está regulamentada, o encerramento desse período de aprendizado é avaliado por meio de um exame onde o aprendiz constrói sozinho um órgão de tubos, em geral pequeno, mostrando assim que o aprendiz tem domínio sobre todas as etapas do processo e pode, se aprovado, abrir uma empresa e ensinar seus oficiais e aprendizes. Portanto, em 
um cenário como este, a manutenção do patrimônio organológico é difícil ou mesmo quase impossível.

Insistiu-se várias vezes que os primeiros responsáveis pela boa manutenção dos instrumentos são seus proprietários, e é necessário que, quando contratam um serviço, informem-se a respeito do trabalho a ser executado, das reais necessidades de restauro e da qualidade do serviço a ser prestado. Em caso de dúvida, é preciso que a interferência no instrumento seja mínima, apenas para possibilitar que ele volte a soar, impedindo assim que peças originais sejam perdidas para sempre, e que o órgão seja tão modificado, que suas características originais desapareçam.

Aos organistas, corresponsáveis pela manutenção e bom uso dos instrumentos, é recomendado um maior conhecimento da arte organária. Percebe-se, muitas vezes, que os instrumentistas querem um instrumento bom para tocar, sem se preocupar com as questões técnicas que compõem cada órgão. Como existem muitas formas de juntarem-se os elementos essenciais que formam o órgão - foles, sistema de distribuição de ar, e tubos - é preciso que os intérpretes, quando estão diante de um instrumento desconhecido, tenham paciência e tempo para ouvir o que o mesmo tem a dizer e capacidade para, a cada nova experiência, adaptar seu repertório e a forma de tocar. E, ainda, que tratem o instrumento com o respeito devido.

Aqui se quer mostrar que o processo de conservação dos instrumentos envolve outros agentes importantes. Ao estado cabe a função de regulamentar, controlar e exigir qualidade nos trabalhos realizados. Infelizmente, os órgãos enquanto objetos individuais ainda não são tombados, sobretudo os mais recentes. Se, por um lado, as leis de incentivo permitem acesso a verbas, por outro, os instrumentos ficaram mais vulneráveis a grandes restauros feitos sem cuidados. E também os patrocinadores devem exercer sua parcela de colaboração, exigindo bons projetos e participação de profissionais competentes, que tenham um histórico de trabalhos bem realizados e boas indicações. Hoje, devido ao fato de passar a organaria internacional por graves crises, recebemos no Brasil a visita de diversos organeiros europeus à procura de trabalho, um fato que desperta um alerta específico.

Por fim, os pesquisadores de diversas áreas, de música e de história até à de física e à de química, cujas informações teóricas e empíricas, produzidas por meio de uma abordagem científica, muito colaboraram no processo de restauro dos instrumentos e na forma de os músicos entenderem o uso a ser dado a eles. No entanto, é preciso que essas informações sejam corretas quanto aos dados técnicos relativos à organaria, o que se dá por meio da convivência com organeiros bem formados e da possibilidade de trabalho conjunto. E, sempre neste sentido, coloca-se a importância da criação de, cada vez mais, novos fóruns de discussão a respeito do restauro dos instrumentos ou de sua ampliação, possibilitando a participação de outros segmentos responsáveis pelo patrimônio histórico brasileiro na tomada de decisões relativamente a uma questão que, talvez, antes deste momento, nunca fora tratada de forma sistematizada e que alguns sinais positivos indicam ter verdadeiras chances de sofrer avanços definitivos rumo a uma solução responsável. 


\section{REFERÊNCIAS}

AMSTALDEN, J. C. A música na igreja católica no Brasil após o Concílio Vaticano II. 2001. Dissertação (Mestrado em Música) - Universidade Estadual Paulista Júlio de Mesquita Filho, São Paulo, 2001.

BACCI, M. et al. Innovative sensors for environmental monitoring in museums. Sensors, v. 8, n. 3, p. 1984-2005, 2008.

BATISTA G. S. Os órgãos de tubos de Guilberme Berner na cidade do Rio de Janeiro. 2009. Dissertação (Mestrado em Música) - Universidade Estadual Paulista Julio de Mesquita Filho, São Paulo, 2009.

KERR, D. M. Órgãos tubulares da cidade do Rio de Janeiro: estudo e catalogação. In: CONGRESSO DA ANPPOM, 17. 2007, São Paulo. Anais..., 1. São Paulo: Editora da Unesp, 2007. p. 1-9.

BERGSTEN, C. J. et al. Corrosion of Lead and Lead-Tin Alloys of Organ Pipes in Europe. Projeto N.: EVK4-CT-2002-00088, 2003-2005. Disponível em: <http://goart.gu.se/collapse/>.

Sensor system for detection of harmful environments for pipe organs (Sensorgan). In: INDOOR AIR QUALITY 2008 MEETING, 8., 17-19 abr. 2008, Viena. Resumos... Disponível em $<$ http://iaq.dk/iap/iaq2008/2008_contents.htm>.

BERNARDI, A. Microclimate in the British Museum, London. Museum Management and Curatorship, London, v. 9, p.169-182, 1990.

BOVET, G.; FREIXO, E. Relatório à Funarte sobre a visita a órgãos bistóricos em São Paulo, Belém, Recife, Babia e Minas Gerais. [s. 1., s. n.], 1987.

BRESCIA, M. A. Catalogue des orgues baroques au Brésil. Architecture et décoration. 2008. Dissertação (Mestrado em História da arte e Musicologia) - Université Sorbonne, Paris IV, Paris, 2008

CAMUFFO, D. et al. Church beating and preservation of the cultural beritage: a practical guide to the pros and cons of various heating systems [Il riscaldamento nelle chiese e la conservazione dei beni culturali: guida allfanalisi dei pro e dei contro dei vari sistemi di riscaldamento]. Milano: Electa Mondadori, 2007.

CASSAR, M. Environmental management guidelines: for museums and galleries. London: Routledge, 1995.

CHIAVARI, C. et al. Atmospheric corrosion of historical organ pipes: the influence of environment and materials. Corrosion Science, v. 50, p. 2444-2455, 2008.

CLARKE, T. Organ failure. Nature, v. 427, p. 8-9, 2004.

CURT LANGE, F. História da música nas Irmandades de Vila Rica, 1. Belo Horizonte: Arquivo Público Mineiro, 1979.

História da música nas Irmandades de Vila Rica, 5. Belo Horizonte: Imprensa Oficial do Estado de Minas Gerais, 1981. 
DINIZ, J. C. Organistas da Babia: 1750-1850. Rio de Janeiro: Tempo Brasileiro, 1986.

FERREIRA, M. M. Arp Schnitger: dois órgãos congêneres de 1701, suas destinações atuais e características técnicas. s.d. Tese (Doutorado em Música) - Instituto Pontificio di Musica Sacra, Roma, 1985.

FREIXO E. Os órgãos brasileiros do século XVIII: o órgão no Brasil Colônia. In: NERY, R. V. (Ed.). A música no Brasil colonial. Lisboa: Fundação Calouste Gulbenkian, 2000. p. 417-424.

Órgão Arp Schnitger, Sé de Mariana, Minas Gerais: Aspectos históricos e técnicos. Mariana: Arquidiocese de Mariana, 2002.

FRONER, Y. A.; ROSADO, A. Princípios históricos e filosóficos da conservação preventiva. Belo Horizonte: Escola de Belas Artes-UFMG; Iphan, 2008.

KERR, D. M. Possíveis causas do declínio do órgão no Brasil. 1985. Dissertação (Mestrado em Música) - Universidade Federal do Rio de Janeiro, Rio de Janeiro, 1985.

KERR, D. Catálogo de órgãos da cidade de São Paulo. São Paulo: Annablume, 2001.

; CARVAlHO, A. R. A pesquisa sobre o órgão no Brasil: estado da arte. Per Musi. Belo Horizonte, v. 12, p. 25-38, jul.-dez. 2005.

NIKLASSON, A. Atmospheric corrosion of bistoric lead organ pipes. 2007. Tese (Doutorado em Química) - Chalmers University of Technology, Göteborg, 2007.

et al. Air pollutant concentrations and atmospheric corrosion of organ pipes in European church environments. Studies in Conservation, v. 53, n. 1, p. 24-40, 2008.

PARRA, G. D.; CASTELLANOS, O. G. Órganos bistóricos de Oaxaca. Estúdio y catalogación. México City: Fomento Cultural Banamex, 1999.

PAUlA, T. C. T. de Plenderleith a Al Gore. O ideário vigente na conservação de bens culturais móveis no século XXI. Anais do Museu Paulista, São Paulo, v. 16, n. 2, p. 241-264, jul.-dez. 2008.

RISHOLM-SUNDMAN, M. et al. Emission of acetic acid and other organic compounds from different species of solid wood. Holz als Rob-und Werkstoff, v. 56, n. 2, p. 125-129, 1998.

SCHNEIDER, A. Os órgãos de tubos no Rio Grande do Sul. Porto Alegre: [s. n.], 1994.

SILVA, H. C. P da. O Órgão setecentista da igreja do Carmo de Diamantina: seus enigmas e sua estreita ligação com o Órgão de Córregos. 2008. Dissertação (Mestrado em Música) - Universidade Estadual de Campinas, Campinas, 2008.

SNYDER, K. J. (Org.). The organ as a mirror of its time. North European reflections, 1610-2000. New York: Oxford University Press, 2002a.

Organs as historical and aesthetic mirrors. In: SNYDER, K. J. (Ed.). The organ as a mirror of its time. North European reflections, 1610-2000. New York: Oxford University Press, 2002b. p. $1-22$.

Annals of Museu Paulista. v. 18. n.1. Jan. - Jun. 2010. 
A new organ for a new millennium. In: SNYDER, K. J. (Ed.). The organ as a mirror of its time. North European reflections, 1610-2000. New York: Oxford University Press, 2002c. p. 339-346.

SOARES, C. Os órgãos Cavaillé-Coll das igrejas do Senhor Bom Jesus, do Brás, e São José, do Ipiranga, na cidade de São Paulo e da igreja da Ordem Terceira do Carmo, Salvador, Bahia. Revista Goiana de Artes, Goiânia, v. 10, n. 1, p. 71-93, 1989.

Notice sur les orgues Cavaillé-Coll existants au Brésil. La flute harmonique, Paris, v. 57-58, p. 52-65, 1991.

O órgão, sua música e os compositores. Diário Internacional de Música Clássica, Espanha, março de 2001. Disponível em: <www.mundoclasico.com>.

SOUZA, L. A. C. A Importância da Conservação Preventiva. Revista da Biblioteca Mário de Andrade, São Paulo, v. 52, p. 87-93, 1994.

THOMSON, G. The museum environment. Oxford: Butterworth-Heinemann, 1986.

VAN DER BRINK, O. F.; EIJKEL, G. B.; BOON, J. J. Dosimetry of paintings: determination of the degree of chemical change in museum-exposed test paintings by mass spectrometry. Thermochimica Acta, Amsterdam, v. 365, p. 1-23, 2000.

WALLER, R. Conservation risk assessment: a strategy for managing resources for preventive conservation. In: ROY, A.; SMITH, P. (Eds.). Preventive conservation practice, theory and research. Preprints of the contributions to the Ottawa Congress, 2., September 1994. London: The International Institute for Conservation, 1994. pp. 12-16.

SITES

<http://www.arpschnitger.nl> Acesso em 20 nov. 2009.

<http://goart.gu.se/collapse/> Acesso em 20 nov. 2009.

<http://www.grenzing.com> Acesso em 20 nov. 2009.

<http://iaq.dk/iap/iaq2008/2008_contents.htm> Acesso em 20 nov. 2009.

$<$ http://www.luteranos.com.br/attachments/centrorio/Artigo_sobre_orgao_Walcker_2198.pdf $>$. Acesso em 20 nov. 2009.

<http://www.mundoclasico.com>. Acesso em 20 nov. 2009.

<http://www.orgaodase.com.br>. Acesso em 20 nov. 2009.

<http://www.santuariofatima.com.br/exibe_noticia.php?not=125>. Acesso em 20 nov. 2009.

<http://sptv.globo.com/Sptv/0,19125,LPO0-6150-20080712-325480,00.html>. Acesso em 20 nov. 2009 (Entrevista).

<http://sptv.globo.com/Sptv/0,19125,LPO0-6146-20070412-275830,00.html>. Acesso em 20 nov. 2009 (Entrevista). 
Protocolo de Oaxaca: disposições regulamentadoras para a restauração de órgãos na América Latina (2001)

I. Introdução

A. Este protocolo é o resultado da conferência realizada de 29 de novembro a 3 dezembro de 2001 na cidade de Oaxaca, México, pelo Instituto de Órgãos Históricos de Oaxaca, em parceria com o Instituto Nacional de Antropologia e História, o Instituto Nacional de Belas-Artes, - Conselho Nacional para a Cultura e as Artes, o Instituto Oaxaquense das Culturas, as Embaixadas da Espanha, França, Holanda, Uruguai e Suíça no México, bem como a Sociedade Amigos de Oaxaca.

Tem-se como objetivo que sirva como modelo que possa ser adotado e adaptado para sua própria utilização tanto por governos estaduais como nacionais, de modo especial os do México e dos demais países da América Latina em seus esforços para proteger os órgãos históricos de sua região.

B. Definição de um órgão histórico

Para as finalidades deste documento, um órgão será considerado histórico se sua construção datar de antes do ano de 1900.

II. Regulamento Geral

A. Da parte de todos os envolvidos na restauração de um órgão histórico

1. Todas as partes concordam que um órgão histórico é parte constituinte do patrimônio nacional e se comprometem a tratá-lo com o respeito que the é devido.

2. Além disso, todas as partes concordam que um órgão histórico é parte integrante do patrimônio internacional.

3. Todas as partes concordam que um órgão histórico, como parte do patrimônio nacional e internacional, deve ser acessível a acadêmicos, historiadores, construtores e executantes.

4. Todas as partes concordam em não participar em nenhum projeto que envolva um órgão histórico que não cumpra com as disposições deste protocolo.

5. Todas as partes estarão de acordo em participar de um projeto que envolva um órgão histórico com pessoas que cumpram com as disposições deste protocolo.

6. Todas as partes estarão de acordo em respeitar as decisões tomadas por qualquer um dos comitês descritos neste protocolo quando se encontrar em um projeto que envolva um órgão histórico.

7. Quando se encontrarem em um projeto que envolva um órgão histórico, todas as partes concordarão em respeitar as disposições locais, estaduais e federais vigentes.

8. Todas as partes reconhecem que a restauração de um órgão histórico pode ser um processo contínuo que compreende diferentes etapas de consolidação, conservação e restauração, que em determinados momentos poderão incluir diversos projetos de restauração.

B. Do guardião* de um órgão histórico

1. O guardião está de acordo em fazer todo o esforço possível para assegurar a disponibilidade do instrumento para sua visita, inspeção e uso apropriado por parte de instituições governamentais,

Annals of Museu Paulista. v. 18. n.1. Jan. - Jun. 2010. 
organizações civis regionais, ONGs* com interesses legítimos, acadêmicos, construtores de órgãos e executantes qualificados.

2. O guardião está de acordo em limitar o acesso até o interior da caixa do órgão apenas a visitantes autorizados.

3. O guardião está de acordo em limitar [o acesso a] uma parte ou todo o trabalho no instrumento apenas ao pessoal autorizado.

4. O guardião reconhece a importância de seu papel em proteger o órgão da terra, umidade excessiva, animais, uso inapropriado, vandalismo etc.

5. O guardião reconhece a importância de seu papel na promoção da conscientização, dentro da comunidade local, do que significa um órgão histórico.

6. O guardião reconhece a importância de seu papel na continuação da integração de um órgão histórico dentro da vida religiosa e musical da comunidade.

\section{Do patrocinador}

1. O patrocinador reconhece que as disposições contidas neste acordo podem aumentar substancialmente o custo de restauração de um órgão.

2. $\bigcirc$ patrocinador reconhece que aquele que orça o preço mais baixo para um projeto de restauração, poderá não ser o mais qualificado.

3. O patrocinador está de acordo em não tratar a restauração de um órgão histórico meramente como uma transação comercial.

4. $\bigcirc$ patrocinador está de acordo de que é melhor financiar de forma adequada um número menor de projetos de restauração do que um número maior deles de forma inadequada.

5. O patrocinador está de acordo em solicitar procedimentos de contabilidade e condições financeiras apropriados por parte do restaurador.

6. O patrocinador reconhece que as características de um órgão histórico em particular são em grande parte determinadas por estilos nacionais, regionais e locais, e que estes estilos também refletem períodos cujas características vão se modificando com o tempo.

7. $O$ patrocinador reconhece, por isso, que um restaurador em potencial deve demonstrar por meio de seu trabalho prévio que se respeita tudo aquilo que se espera com relação a estilos e cronologias nacional, regional e local.

8. O patrocinador está de acordo em assegurar-se de que o restaurador seja devidamente qualificado por meio de provas abundantes por parte de especialistas em matéria de construção e restauração de órgãos, estando de acordo em consultar especialistas em particular que possuam um conhecimento específico do estilo de construção do órgão em questão.

9. O patrocinador está de acordo em não financiar um projeto que não inclua um orçamento para coletar, organizar e publicar a documentação prévia à restauração e da própria restauração.

10. O patrocinador está de acordo em pagar ao restaurador pelo menos em três prestações, dentro dos detalhes exatos do programa de pagamento que deverá aprovar o Comitê de Restauração.

1 1. O patrocinador está de acordo em reter o segundo pagamento até que toda a documentação prévia à restauração tenha sido completada e submetida a todas as partes descritas neste protocolo.

12. O patrocinador está de acordo em reter o último pagamento até o momento em que a totalidade dos relatórios descritos neste acordo tenham sido submetidos e aprovados por todas as partes descritas neste protocolo.

13. O patrocinador está de acordo em suspender o financiamento de um projeto de restauração se assim o recomendar o Comitê de Restauração. 
14. O patrocinador reconhece que parte do custo de um projeto de restauração deverá incluir também um fundo para o uso e manutenção do instrumento após sua restauração.

15. O patrocinador está de acordo em financiar projetos que tenham como objetivo suplementar completar projetos anteriores de restauração que possam não ter recebido financiamento adequado para finalizar a restauração ou para os quais houve limitações dentro de um projeto anterior de restauração devido a uma falta prévia de conhecimentos que se requeria para completar os projetos de restauração.

16. O patrocinador está de acordo em considerar o financiamento de projetos de documentação de instrumentos restaurados antes de que este acordo entre em vigor.

D. Do restaurador de um órgão histórico

1. O restaurador está de acordo em trabalhar dentro dos limites de sua competência pessoal e está de acordo em subcontratar quaisquer outros trabalhos.

2. O restaurador está de acordo em subcontratar o trabalho daqueles que tenham recebido a aprovação do Comitê de Restauração.

3. O restaurador reconhece a importância de pesquisas publicadas e informação que tenha sido submetida a revisão formal e vai esforçar-se em manter-se informado mediante informação atualizada no que concerne tanto a materiais quanto a métodos.

4. O restaurador está de acordo em trabalhar em uma atmosfera de cooperação e abertura, consentindo, dentro de limites razoáveis, tornar acessível todos os espaços de trabalho a visitas de representantes de setores governamentais e de organizações civis regionais (ONGs) com interesses legíitimos, bem como a acadêmicos qualificados, construtores de órgãos e organistas determinados pelo Comitê de Restauração.

5. O restaurador está de acordo em apresentar todo o orçamento por escrito de forma precisa e honesta, até onde for possível, e de tal modo que reflita os custos reais e completos de uma restauração profissional e responsável.

6. O restaurador está de acordo em não aceitar um projeto no qual o financiamento proposto é inadequado para poder realizar o projeto de forma profissional e responsável.

7. Se, por razões difíceis de predizer, o orçamento do financiamento mostra-se insuficiente para o projeto de restauração, o restaurador está de acordo em não tomar nenhuma decisão que comprometa a qualidade da restauração; o trabalho deverá ser reduzido ou suspenso até o momento em que o financiamento adequado se apresente.

8. Se durante o projeto de restauração chegar-se a dispor da informação sobre qual seja a causa da mudança de orçamento, o restaurador está de acordo em apresentar um novo orçamento e torná-lo conhecido do patrocinador, do guardião, dos organismos governamentais pertinentes e das ONGs regionais.

9. Se houver um aspecto em particular da restauração que é demasiado caro em relação aos recursos disponíveis, o restaurador está de acordo em deixar pendente tal aspecto da mesma, em vez de comprometer esta parte da restauração.

10. Se qualquer aspecto em particular de uma restauração não for entendido adequadamente a partir da informação disponível, o restaurador está de acordo em deixar pendente este aspecto da mesma, em vez de comprometer esta parte da restauração.

1 1. O restaurador está de acordo em manter uma contabilidade precisa e completa do projeto de restauração e de submeter a contabilidade financeira ao guardião, ao patrocinador, aos organismos governamentais e às ONGs regionais.

12. O restaurador está de acordo de que a informação e os dados reunidos durante uma restauração não possuem um caráter de propriedade exclusiva e compromete-se a pôr à disposição toda a informação e dados que forem se acumulando durante o processo de restauração tal como foi definido neste acordo para o guardião, o patrocinador, os organismos governamentais

Annals of Museu Paulista. v. 18. n.1. Jan. - Jun. 2010. 
pertinentes, as ONGs regionais e qualquer outra instância ou indivíduos que determine o Comitê de Restauração.

13. O restaurador está de acordo em incentivar o guardião do instrumento, logo após sua restauração, a pôr o mesmo à disposição para sua inspeção periódica pelos organismos governamentais e ONGs regionais apropriadas.

14. O restaurador está de acordo em incentivar o guardião do instrumento a colocá-lo à disposição para visitas, ensaios e execução por executantes qualificados.

15. O restaurador está de acordo em promover ativamente a conscientização das disposições deste protocolo.

16. O restaurador está de acordo em respeitar a integridade dos colegas restauradores e da profissão de restaurador como um todo, e não disseminará informação falsa ou imprecisa a colegas restauradores.

17. O restaurador está de acordo de que qualquer opinião expressa sobre o trabalho de colegas restauradores será baseada na experiência profissional e não por ouvir dizer.

E. Sobre os membros do Comitê e outros especialistas

1. Os membros de qualquer comitê definidos neste acordo não receberão nenhum pagamento por serviços prestados segundo este protocolo.

2. Os especialistas ou membros do comitê envolvidos em um projeto de restauração desculpar-se-ão em respeito a seu papel no projeto se houver alguma possibilidade de conflitos de interesses.

3. Os especialistas ou membros do comitê envolvidos em um projeto de restauração estão de acordo em emitir juízos de modo imparcial e profissional, baseados, até onde for possível, na sua própria experiência e não de ouvir dizer.

III. Padrões de procedimento

\section{A. Princípios Gerais}

1. É preciso manter um equilíbrio entre a necessidade da sociedade de usar sua propriedade cultural e de preservar essa mesma propriedade, particularmente no caso de um instrumento musical cuja intenção era usá-lo de forma consistente.

2 Em qualquer restauração, por mais bem elaborada que seja, perde-se informação valiosa, de modo que as partes envolvidas em um projeto de restauração não poderão admitir automaticamente que é sempre desejável restaurar um órgão histórico.

3. Em muitos casos um projeto, mais do que uma restauração completa, pode ser o que se precisa.

i. Em alguns casos, apenas uma consolidação ou uma limpeza do instrumento poderá ser o adequado. Atividades como essas são propriamente chamadas de esforços de conservação*.

ii. Em alguns casos, a reparação dos foles, permitindo com isso que o órgão recupere sua sonoridade sem nenhuma outra restauração, poderá ser o apropriado.

iii. Caso um órgão tenha sofrido drásticas alterações, ou que muitas de suas partes (por exemplo, a tubaria) tenha se perdido completamente, deverá ser efetuado um projeto de reconstrução*.

iv. Caso o órgão seja de extremo significado histórico e/ ou que não exista conhecimento suficiente para restaurar o instrumento de maneira adequada, deve-se realizar um projeto para a criação de uma réplica* de tal instrumento. 
4. Os instrumentos que têm um período maior de existência adquirem inevitavelmente uma gama de acréscimos e modificações que são parte da história do instrumento. Estes acréscimos podem servir de interesse tanto a acadêmicos quanto a executantes, pois lançam luz quanto ao uso do instrumento. Tais acréscimos devem ser examinados individualmente e retirados depois de uma cuidadosa consideração e profunda documentação.

5. Todas as partes estão de acordo em fazer todo o esforço possível em resguardar materiais antigos para restaurações ou alguma reparação.

6. Se, após todo o esforço possível feito para resguardar os materiais antigos, faz-se necessário substituir uma parte do instrumento, a parte velha será guardada em um lugar seguro e permanecerá no mesmo lugar, ou no centro da região, devidamente etiquetada com respeito a seu conteúdo e significado e colocar-se-á à disposição de pesquisadores qualificados.

7. Serão feitas tão somente aquelas mudanças que sejam absolutamente necessárias.

8. Todas as mudanças ou reparações que se façam deverão ser de natureza reversível.

9. A fim de assegurar-se de que todas as mudanças são reversíveis, nenhuma mudança, por menor que seja, se fará sem a documentação detalhada prévia e posterior a intervenção.

10. Não se utilizará nenhum material ou método na restauração de um instrumento que afete de forma desfavorável seu valor como artefato cultural.

11. Todos os novos materiais que forem usados em uma restauração deverão estar, até onde for possível, em total conformidade com os materiais antigos que foram utilizados no órgão ou que sejam típicos de outros órgãos do mesmo estilo e cronologia.

12. Todos os métodos de construção que forem usados na restauração de um órgão histórico deverão estar em conformidade com os métodos de construção originalmente usados na construção do instrumento ou dos instrumentos do mesmo estilo e cronologia.

13. Todas as decisões referentes a restaurações deverão ser estilisticamente apropriadas ao instrumento em questão e relevantes aos estilos locais de construção de órgãos.

14. Todos os restauradores reconhecem a importância de entender o estilo local e de reconhecer a importância dos textos literários publicados sobre o tema.

15. Um órgão histórico deve ser considerado como um todo, mesmo quando um projeto particular de restauração estiver limitado a certos aspectos do instrumento. A restauração das caixas, por exemplo, não deve ser feita separadamente sem que exista uma avaliação completa do instrumento e leve-se em consideração um plano total de restauração. (B. 1).

B. Antes da restauração de um instrumento

1. Nenhum instrumento deverá ser considerado separadamente, mas antes como parte de um recurso integrante maior da região. Antes de atribuir a um instrumento em particular qualquer consideração quanto à restauração, deverá ser feita uma consulta profunda e correta ao inventário dos instrumentos da região, ao qual, dali em diante, será feita referência como Inventário Regional Ise tal Inventário não existir, então deve-se proceder a sua preparação, esforçando-se o máximo para datar cada um dos instrumentos e obter desta maneira uma história da construção dos órgãos da região). Deverá ser preparado um plano regional que leve em consideração o número de órgãos não restaurados na região, bem como seus períodos (ciclos). A decisão sobre se deve-se ou não restaurar um órgão partirá do respeito a este plano, evitando a restauração ao mesmo tempo de todos os órgãos provenientes de um determinado período e até mesmo deixando um instrumento importante de cada período sem restauração como referência.

2. Antes da restauração de qualquer instrumento, deverá ser elaborado um Plano de Utilização. Com que propósito se restaura o instrumento? Quem vai tocar o órgão? As pessoas da comunidade terão a oportunidade de aprender a tocar o órgão? Quem fará a manutenção

Annals of Museu Paulista. v. 18. n.1. Jan. - Jun. 2010. 
do instrumento? De onde virão os recursos para pagar os executantes, maestros e pessoal da manutenção?

3. Antes da restauração de qualquer instrumento, deverá ser preparada a Documentação Prévia a Restauração (se já não existe). Esta Documentação deverá incluir, sem por ela estar limitada, um inventário completo das flautas com suas respectivas medidas e composição dos registros compostos; medidas e desenhos dos "someiros", caixas, mecanismo, sistema de ar e ferraria, bem como uma análise e avaliação da decoração do instrumento. Tudo isso deverá ser realizado da melhor maneira possível, isto é, sem desmontar o órgão.

4. Qualquer amostra* será feita com o pleno conhecimento e permissão do guardião, bem como dos organismos governamentais pertinentes.

5. Antes da restauração de qualquer instrumento, será preparado um documento fotográfico completo das condições anteriores à restauração do instrumento.

6. Deverá ser preparado um parecer honesto e completo do significado histórico-cultural do órgão. Tanto a favor de uma restauração que inclua uma lista de todos os riscos quanto a segurança e integridade do instrumento que podem ocorrer, quanto contra a restauração que inclua todos os perigos de uma restauração, para que se possa tomar decisões racionais com respeito a uma eventual restauração do instrumento.

C. Comitê de Restauração

1. Antes da restauração de um instrumento será formado um comitê integrando pelo menos três especialistas ao qual nos referiremos como o Comitê de Restauração.

2. O restaurador deverá submeter a lista dos membros do Comitê ao guardião, ao patrocinador, aos organismos governamentais e ONGs regionais pertinentes para sua aprovação, bem como uma lista de possíveis membros que possam ser alternados.

3. O restaurador não fará parte do Comitê de Restauração.

4. Os membros do Comitê de Restauração concordam em trabalhar dentro dos limites de sua competência pessoal.

5. Os membros do Comitê de Restauração concordam em familiarizar-se com o estilo e o período de construção de órgãos do órgão em questão.

6. Os membros do Comitê de Restauração deverão consultar outros especialistas no assunto antes de tomar qualquer decisão.

7. O Comitê de restauração terá como responsabilidade revisar o Inventário Regional, o Plano de Utilização, bem como os pontos a favor e contra a restauração, fazendo uma recomendação indicando se continua-se ou não a restauração.

8. O Comitê de Restauração não recomendará nenhum projeto para o qual não se tenha preparado e arquivado com as entidades definidas neste protocolo o Inventário Regional completo, o Plano de Utilização, a Documentação Prévia a restauração e os pontos a favor e contra a restauração.

9. O Comitê de Restauração se encarregará de verificar quais os especialistas nacionais e internacionais no campo da construção e restauração de órgãos terão acesso ao Inventário Regional, ao Plano de Utilização, a Documentação Prévia a restauração e os pontos a favor e contra a restauração

10. Se o Comitê de Restauração concordar com a idéia de restaurar um instrumento em particular, será então feita uma solicitação ao restaurador para que envie uma Proposta de Restauro. A proposta deve incluir, sem estar por ela limitado, uma descrição completa do trabalho e métodos planejados, a disposição proposta, registro, pressão do ar e afinação e o que exatamente será feito com cada um dos principais elementos do instrumento, principalmente o trabalho nos tubos, no someiro ("segredo"), ação, sistema de ar e a caixa. 
1 1. O Comitê de Restauração atribuirá um preço à Proposta de Restauro e preparará um Relatório de Avaliação por escrito o qual deverá incluir toda e qualquer alteração à Proposta de Restauração sugerida pelo Comitê de Restauração.

12. O Comitê de Restauração deverá arquivar seu Relatório de Avaliação com todas as entidades indicadas neste Protocolo.

13. O Comitê de Restauração examinará o Plano de Restauração já revisto para assegurar-se de que as mudanças recomendadas tenham sido incorporadas.

14. O Comitê de Restauração assegurar-se-á de que o Plano de Restauração revisado permaneça arquivado com as entidades indicadas nesta Proposta.

15. O Comitê de Restauração também será responsável por assegurar-se de que as comunidades organísticas nacionais e internacionais tenham acesso programado aos relatórios exigidos por este protocolo, incorporando dentro de suas recomendações as opiniões desta comunidade de maior importância.

\section{Restauração}

1. Deverão ser estabelecidas instalações adequadas para o trabalho e armazenamento que garantam que o artefato cultural que está sendo restaurado esteja seguro, bem como a integridade dos trabalhadores envolvidos na restauração.

2. O restaurador tem a obrigação de elaborar e manter registros corretos, completos e permanentes relativos ao exame, amostragem, investigação científica e tratamentos realizados durante o processo de restauração.

3. Serão estabelecidos procedimentos adequados para a documentação do trabalho de restauração. Cada flauła, válvula, vareta, tecla terá um determinado número de inventário. Será atribuído um número para cada peça. Todo trabalho realizado permanecerá baseado neste registro.

4. Qualquer parte do órgão será manuseada o menos possivel, e só se manuseará o necessário para que a parte volte a funcionar novamente.

5. As considerações de tipo visual não são uma justificativa adequada para alterar qualquer parte em funcionamento de um órgão histórico.

6. A limpeza será feita de modo judicioso, considerando que, se é feita sem o devido discernimento, pode-se apagar informação valiosa.

7. As peças sobressalentes devem conformar-se, tanto quanto for possível, aos materiais e aos detalhes estilísticos da construção (por exemplo, a entonação das flautas) em relação a todo o resto do instrumento e de outros instrumentos da região.

8. Todos os elementos do sistema que determinam as características do ar de um órgão deverão ser restaurados de modo exato ou replicados, utilizando aquelas medidas determinadas no mesmo local, ou com referência a outros instrumentos comparáveis na região. Um sistema de alimentação suplementar, acionado mecanicamente, poderia ser adicionado se julgado apropriado por todas as partes, sempre e quando não alterar de forma significativa as características originais do sistema de ventilação do órgão.

9. Todos os elementos de ação do órgão (teclas, varetas, válvulas, tábuas de redução, canais de ar, capacidade dos someiros [segretos]) serão restaurados exatamente com o mesmo desenho, dimensão e material, ou replicados, usando aquelas medidas determinadas ali mesmo, ou com referência a outros instrumentos comparáveis da região.

10. A restauração da pintura/decoração será contratada separadamente, com especialistas reconhecidos que tenham o conhecimento de estilos, materiais, técnicas e métodos regionais. 
11. Todo o trabalho que se contrate separadamente deverá ser adequadamente supervisionado e documentado. As condições de trabalho e armazenamento deverão seguir os mesmos modelos daqueles que se estabeleceram neste acordo para o restaurador.

12. Todo trabalho contratado separadamente e espaços de trabalho deverão estar disponíveis para sua inspeção pelas mesmas entidades a que se permitiu o acesso ao espaço de trabalho do restaurador, de acordo com as disposições deste acordo.

\section{E. Manutenção e consertos}

1. O restaurador concorda em proporcionar ao patrocinador e ao guardião um programa de manutenção que determine quais os tipos de manutenção rotineira se fazem necessários para o instrumento e que tão frequentemente se requer do instrumento.

2. O restaurador deverá estar disponível para dar a manutenção necessária ao órgão restaurado; se não for possível, proverá o guardião com a informação necessária para contatar pessoal capacitado para sua manutenção.

3. Os mesmos procedimentos e regras serão aplicadas aos reparos e restaurações, incluindo o uso de materiais, métodos e documentação.

4. Deverá ser feita uma lista de problemas rotineiros de manutenção que não requeiram a aprovação do guardião, do patrocinador e dos organismos governamentais. $\bigcirc$ guardião, o patrocinador e os organismos governamentais deverão dar sua aprovação à lista em questão.

5. Não serão tomadas decisões repentinas no que se refere a reparação do instrumento baseadas apenas na necessidade de fazer o instrumento funcionar, mesmo quando for para um concerto, serviço religioso ou gravação.

\section{GLOSSÁRIO}

Guardião: é a entidade encarregada da proteção do órgão. No geral são as autoridades da comunidade, o comitê da igreja e/ou o sacristão.

ONG: refere-se a uma Organização Não Governamental.

Amostra: refere-se à remoção de quantidades diminutas de material para fins de análise científica do material em questão.

Conservação: refere-se àquelas atividades direcionadas a conservar o instrumento tal qual existe, sem nenhum tipo de restauração, reconstrução ou outra modificação. As atividades de conservação estão limitadas àquelas que ajudem a prevenir qualquer deterioração futura da condição atual em que se encontra $\mathrm{O}$ instrumento.

Reconstrução: refere-se àquelas atividades que envolvam um instrumento que tenha sido alterado radicalmente, ou que tenha perdido muito de seu material original. Uma reconstrução deve estar baseada em informação reconhecida de instrumentos do mesmo estilo e período ou muito semelhantes.

Réplica: é uma cópia a mais fiel possível do original de um instrumento histórico construído para fins de estudo e execução. A réplica de um instrumento deverá ser feita naqueles casos em que um instrumento possui um valor histórico incalculável e/ou de onde não exista informação suficiente para uma restauração adequada.

Restaurador: entende-se como um construtor de órgãos e/ou consultor/coordenador de um projeto.

Artigo apresentado em 12/2009. Aprovado em 4/2010. 